\title{
Bibliográfia
}

\section{A 2015-ben megjelent, jog- és államtudományi tárgyú könyvek annotált bibliográfiája 1. rész}

Folyóiratunkban rendszeresen jelenik meg az elmúlt időszak új, hazai szakkönyveiről készült, annotált bibliográfia. Az annotáció a könyv felhasználhatóságáról írott, rövid, tényszerü leírás, amely a bibliográfiai adatok mellett meghatározza a müfajt, illetve röviden körvonalazza a feldolgozott témát és a bemutatott eredményeket is. A mostani számban a 2015-ben megjelent könyvek első részét dolgozzuk fel. Annak megfelelően, hogy a Magyar Tudományos Művek Tára (MTMT) csak a 120 oldal terjedelmet elérő munkákat kezeli önálló kiadványként, az ettől jelentősen elmaradó (90 oldal alatti) kiadványokkal mi sem foglalkozunk. A bemutatás jogterületenként történik, a jogterületek elnevezésének, az egyes jogterületeken belül pedig a szerzők (szerkesztők) nevének ábécérendjében következik.

Első lépésként ezúttal is egy listát állítottunk össze különböző intézményi könyvtári katalógusok, a Magyar Országos Közös Katalógus (MOKKA), illetve az Országos Széchényi Könyvtár interneten is közölt adatai alapján. Emellett kiadók honlapján, hírlevelekben, a szerzők publikációs listáiban és saját könyvespolcainkon is kutattunk. Gyüjtőmunkánkat jelentős mértékben segítette a Debreceni Egyetem Egyetemi és Nemzeti Könyvtára (DEENK), amely köteles könyvtárként a hazai kiadványok gyűjtését, feldolgozását, illetve részben - a mienkhez képest némileg eltérő szempontok szerint - annotálását is elvégzi.

A leírások elkészítése során általában a szerzők, kiadók által készített fülszövegeket, ajánlásokat, illetve a kötetekről készült recenziókat is igyekszünk fellelni és hasznosítani. Az annotációk azonban minden esetben úgy készültek, hogy magát az adott könyvet is a kezünkbe vettük, s ehhez, ha kellett, könyvtárközi kölcsönzéssel vagy más intézményekben dolgozó kollégáktól megkértük. Az annotációk tehát önálló feldolgozó munka eredményei.

Tisztában vagyunk azzal, hogy a feldolgozás szempontrendszere legjobb igyekezetünk ellenére is hiányos, illetve a sok szakterület és közremüködő okán egyenetlen. Örömmel veszünk és meg is szívlelünk ezért minden észrevételt, amely munkánkra vonatkozóan szerkesztőségünkhöz beérkezik. Szívesen fogadjuk azt is, ha a szerzők figyelmünkbe ajánlják saját könyvüket.

A leírások első, rövidebb része tartalmazza a könyvészeti adatokat (cím, szerző/ szerkesztő, a kiadó neve, a kiadás helye és éve) az arra való utalással, hogy van-e a könyvben bibliográfia (irodalomjegyzék), illetve hogy a könyv milyen müfajba sorolha- 
tó be. A terjedelmet oldalszámban adjuk meg, s közöljük a kötet azonosítására szolgáló ISBN-t, illetve sorozatok esetében az ISSN-t is. A második rész röviden leírja az alkotót, illetve alkotókat. Ezt követően (a változatlan utánnyomások kivételével) általában 6-12 sor terjedelemben számba vesszük a mü tárgyköreit, föbb eredményeit. Az eredmények részletes értékelését azonban nem végezzük el (recenziószintü bemutatást nem végzünk). A sokszerzős, illetve a gyüjteményes munkák esetében nem kerül sor valamennyi szerző név szerinti megemlítésére, s a tanulmányok számától, tematikai egymáshoz kapcsolódásától függ, hogy minden témát megnevezünk-e. A felsőoktatási tananyagok, jogszabályközlések bemutatását a lehető legtömörebben végezzük el. A müfaj sajátosságaiból következően az annotáció nem tekinthető az adott müre történő szakirodalmi hivatkozásnak.

Az annotációk szerzői valamilyen formában kivétel nélkül kapcsolódnak a Debreceni Egyetem Állam- és Jogtudományi Karához, legyen szó munkatársainkról, óraadóinkról vagy jelenlegi és volt hallgatóinkról. Az annotációk végén szereplő monogramok feloldása a következő: Antal Zsófia (A. Zs.) joghallgató, Bagossy Mária (B. M.) PhD-hallgató, Balogh Éva (B. É.) egyetemi tanársegéd, Barta Attila (B. A.) egyetemi adjunktus, Besenyei Fruzsina (B. F.) joghallgató, Bordás Péter (B. P.) egyetemi tanársegéd, Deák Viktória (D. V.) PhD-hallgató, Fejesné Varga Zita (F. V. Z.) bírósági tikár és PhD-hallgató, Ferenczy Áron (F. Á.) PhD-hallgató, Ficsor Krisztina (F. K.) egyetemi adjunktus, Gábri Angéla (G. A.) PhD-hallgató, Hadházi Dávid (H. D.) joghallgató, Háger Tamás (H. T.) bíró, óraadó, Horváth Bettina (H. B.) joghallgató, Jakab Viktória (J. V.) joghallgató, Kristóf Nóra (K. N.) joghallgató, Kuprák József (K. J.) joghallgató, Lencse Balázs (L. B.) bírósági titkár és PhD-hallgató, Lovas Dóra (L. D.) PhD-hallgató, Matécsa Bence (M. B.) joghallgató, Nagy Evelin Éva (N. E. É.) joghallgató, Nagy Nelli (N. N.) joghallgató, Pándi Gergő (P. G.) joghallgató, Pápai-Tarr Ágnes (P. T. Á.) egyetemi adjunktus, Puskás Ágnes (P. Á.) PhD-hallgató, Sipos Ferenc (S. F.) egyetemi tanársegéd, Szabó Zsanett (Sz. Zsa.) PhD-hallgató, Szabó Zsófia (Sz. Zs.) PhD-hallgató, Széles Krisztina (Sz. K.) joghallgató, Szendrői Anna (Sz. A.) PhD-hallgató, Szilágyi Dániel (Sz. D.) PhD-hallgató, Tóth Andrea Noémi (T. A. N.) egyetemi tanársegéd, Varga Judit (V. J.) egyetemi tanársegéd, Veszprémi Bernadett (V. B.) egyetemi adjunktus.

\section{ALKOTMÁNYJOG}

- Közjogi átalakulás Magyarországon 2010 és 2015 között

Balázs Ágnes (szerk.)

NKE Szolgáltató Kft., Budapest, 2015

Tanulmánykötet. Terjedelem: 92. Bibliográfia a lábjegyzetekben és a tanulmányok végén. ISBN 9786155527197

- A szerzők a Magyary Zoltán Szakkollégium Közjogi Mühelyének tagjai. A kötet a 2010-es választások után, az új Alaptörvény elfogadásával bekövetkező, az alapjogokat érintő közjogi átalakulások föbb irányait mutatja be, a legfontosabb intézményekre tekintettel. A hat tanulmányban megjelennek az ombudsmani intézménnyel, a külhoni választójog létrehozásával és a választójogi törvénnyel, a 
parlamenti joggal (elsősorban a házszabályi és alkotmányozási folyamatokkal), illetve a 2014-ben átalakuló fővárosi választási rendszerrel, a megyei önkormányzatokkal, valamint a pénzügyi intézményekkel (különösen a Költségvetési Tanácscsal) kapcsolatos aktuális változások. (J. V.)

- Az alkotmányjogi panasz kézikönyve

Bitskey Botond-Török Bernát (szerk.)

HVG-ORAC, Budapest, 2015

Kézikönyv. Terjedelem: 290. Bibliográfia a lábjegyzetekben. ISBN 9789632582795

- Bitskey Botond az Alkotmánybíróság fötitkára, Török Bernát egyetemi oktató. Az elmúlt évek közjogi átalakulása során az Alkotmánybíróság szempontjából is nagy változások következtek be. A testület müködésében meghatározó jelentőségü módosulást jelentettek a hatásköri változások, melyek egyike - az egyéni alapjogi sérelmek hatékony orvoslásának céljából - az alkotmányjogi panaszos eljárás kibővítése volt. Ezáltal a testület a bírói döntések alkotmányossági felülvizsgálatát is végezheti, és az alapjogokkal kapcsolatos jogszabályok értelmezésére is új hatáskörrel rendelkezik. A kötet rendszerezetten dolgozza fel az alkotmányjogi panasz eljárási szabályait, valamint az indítványok formai és tartalmi követelményeit, elemezve az Alkotmánybíróság e hatáskörrel kapcsolatos, 3 éves esetjogát. Elsősorban azok számára tud segítséget nyújtani a kézikönyv, akik beadványukkal az Alkotmánybírósághoz kívánnak fordulni. (B. É.)

- Die bundesstaatlichen Staatsorganisationen

Wilhelm Brauneder-István Szabó (szerk.)

(Sorozat: A Pázmány Péter Katolikus Egyetem Jog- és Államtudományi Karának Könyvei. Tanulmányok, ISSN 2061-7240; 27.)

Pázmány Press, Budapest, 2015

Tanulmánykötet. Terjedelem: 168. Bibliográfia a lábjegyzetekben.

ISBN 9789633082409

- A szerkesztők egyetemi oktatók, kutatási területük az alkotmánytörténet, az államés kormányformák, a parlamentarizmus és az alapjogok. A tanulmánykötet tizenkét tanulmányban mutatja be a szövetségi állami léttel kapcsolatos alkotmánytörténeti kérdéseket Közép-Európa államai, így Németország, Ausztria, Svájc, Liechtenstein és az egykori Jugoszlávia berendezkedésében, továbbá II. Rákóczi Ferenc és Kossuth Lajos konföderációs elképzeléseit is ismertetik az írásokban. A kötetzáró tanulmány a szubszidiaritás elve és a nemzeti parlamentek viszonyát elemzi az Európai Unióban. (N. N.)

- Választási dilemmák: tanulmányok az új választási eljárási törvény nóvumai és első megmérettetése tárgyában

Cserny Ákos (szerk.)

NKE Szolgáltató Kft., Budapest, 2015

Tanulmánykötet. Terjedelem: 262. Bibliográfia a lábjegyzetekben.

ISBN 9786155527067

- A szerkesztő és a tanulmányok szerzői egyetemi oktatók, a téma kutatói. A kötet 
az NKE Választási Rendszerek Kutatómühelyének munkája, tizenegy tanulmányt tartalmaz, amelyek a 2011-es és 2013-as választójogi törvényekkel létrehozott választási mechanizmust elemzik és értékelik. A tanulmányok érintik a választási szervek és megfigyelök, a jelölés és finanszírozás, a kampány és adatvédelem, valamint a szavazási eljárás és szavazási módok témaköreit, ezáltal felölelik a választási eljárási törvény teljes tárgykörét, rávilágítva a választási rendszer mélyebb összefüggéseire. A kötet célja elsősorban a szabályozás anomáliáinak vizsgálata, melynek során az élő joggyakorlatot és a nemzetközi mintákat is figyelembe veszi. (N. N.)

- Az államfö jogállása II.

Csink Lóránt-Szabó István (szerk.)

(Sorozat: Pázmány Péter Katolikus Egyetem Jog- és Államtudományi Karának Könyvei. Tanulmányok, ISSN 2061-7240; 26.)

Pázmány Press, Budapest, 2015

Tanulmánykötet. Terjedelem: 226. Bibliográfia a lábjegyzetekben.

ISBN 9789633082362

- A szerkesztők egyetemi oktatók. A kötetben megjelent tanulmányok a PPKE-n 2013 júniusában megrendezett, az államfő jogállásának témakörével foglalkozó második konferencián elhangzott előadások tanulmánnyá átdolgozott változatai. A tanulmányok több szempontból elemzik a köztársasági elnök jogállását. A kötetben az államfőnek az országot képviselő funkciójával, a kegyelmezési jogkörével, illetve a tisztség magyarországi történeti koncepcióival kapcsolatos tanulmányok szerepelnek. A tanulmányok egyike az intézmény latin-amerikai jellemzőit mutatja be. Az első, ebben a témakörben rendezett konferencia tanulmánykötetének annotációját lásd a Pro Futuro 2015/1. számában. (B. É.)

- Jog és politika határán: alkotmánybíráskodás Magyarországon 2010 után Gárdos-Orosz Fruzsina-Szente Zoltán (szerk.)

HVG-ORAC, Budapest, 2015

Tanulmánykötet. Terjedelem: 409. Bibliográfia a lábjegyzetekben és a fejezetek végén. ISBN 9789632582924

- A szerkesztők egyetemi oktatók. A kötetben szereplő tanulmányok arra a kérdésre keresik a választ, hogy a 2010 után bekövetkező közjogi változások milyen hatással voltak a politika és a jog határán elhelyezkedő Alkotmánybíróság tevékenységére. A kötetben szereplő tanulmányok ezen belül is elsősorban azokra a folyamatokra koncentrálnak, amelyek az Alkotmánybíróság politikai befolyásolását célozták, vagy azt eredményeztek. A kötet szerkesztői kifejezetten érdekesnek és tanulságosnak tekintik e témakörben a magyarországi kétharmados alkotmányozó parlamenti többséggel kapcsolatos tapasztalatokat. A szerzők kutatási területe más és más módon kapcsolódik ehhez a témához, és szakmai álláspontjuk is különböző, így különböző megközelítésű tanulmányokat foglal magában a kötet. (B. É.) 
- Az alkotmányjognak asztalánál: az Alkotmánybiróság belülnézetben Holtó András HVG-ORAC, Budapest, 2015 Monográfia. Terjedelem: 250. Bibliográfia a lábjegyzetekben. ISBN 9789632582641

- A szerző volt alkotmánybíró, müvét „szubjektív szakmai visszatekintésnek” nevezi. A kötet célja a magyar Alkotmánybíróság történeti előzményeinek, létrejötte körülményeinek, müködése kezdeteinek, a teljes ülésen zajlott szakmai vitáknak, illetve a szerző által kiemelt eseményeknek a bemutatása belső nézőpontból. A könyv alapjául azon írott dokumentumok szolgálnak, melyeket a szerző az Alkotmánybíróságon végzett tevékenysége alatt gyüjtött, illetve azon jegyzetek, melyeket munkája során készített. A szerző a magyar alkotmánybíráskodás első nagy korszakát kívánja bemutatni, így a 2010-ben megkezdődött alkotmányos átalakítások utáni korszakról és a testület azt követő müködéséről nem szól. (B. É.)

\section{- Alkotmánytani alapok}

Kocsis Miklós-Petrétel József-TıLk Péter

Kodifikátor Alapítvány, Pécs, 2015

Tankönyv. Terjedelem: 325. Bibliográfia a fejezetek végén. ISBN 9789638991263

- A szerzők a Pécsi Tudományegyetem oktatói. A könyv rendszerezett ismereteket kíván adni az alkotmánytani alapok tekintetében, melynek során célcsoportjának azon hallgatókat tekinti, akik igazságügyi igazgatás vagy jogi felsőoktatási szakképzésről jelentkeznek jogász szakra. A tételes jogi ismeretek mellett segítséget nyújt abban, hogy az alkotmány egészét rendszerben lássuk. Olyan fontos alapfogalmakkal foglalkozik, mint az alkotmányos demokrácia, az alkotmány, a jogállam, a hatalomhoz kapcsolódó kérdések. A könyv teljes képet mutat az alapvető fogalmakról: definiál, kitér a sajátosságokra és bemutatja funkcióikat. Az alapvető jogok témakörét is magába foglalja, kiemelten foglalkozik az emberi jogokkal. (N. E. É.)

\section{- Comparative Perspectives on the Fundamental Freedom of Expression}

András Koltay (ed.)

Wolters Kluwer, Budapest, 2015

Tanulmánykötet. Terjedelem: 624. Bibliográfia a lábjegyzetekben. ISBN 9789632955339

- A szerkesztő egyetemi oktató, a Médiatanács tagja. Az angol nyelvü kötet az MTA és az NMHH együttmüködésében létrejött Médiatudományi Kutatócsoport 2013 és 2016 közötti kutatási programja keretében keletkezett független tanulmányokat, illetve konferencia- előadások tanulmánnyá átdolgozott változatait tartalmazza. A tanulmányok a kifejezés szabadságához kapcsolódó, valamint az egyes médiajogi kérdéseket változatos módon közelítik meg, ami segíthet a „közös európai minimum" megállapításában. A kötet hat nagy szerkezeti egységre tagolódik, az alábbi témakörök szerint: a szólás- és sajtószabadság alapvető elméleti kérdései, az új média szabályozása, az újságírók jogi státusza, az Európai Unió vonatkozó szabályozása, a rágalmazás és a magánszféra védelme, a gyülöletbeszéd korlátozása és a blaszfémia. (B. É.) 
- Sajtószabadság és médiajog a 21. század elején 2.

Koltay András-Török Bernát (szerk.)

Wolters Kluwer, Budapest, 2015

Tanulmánykötet. Terjedelem: 736. Bibliográfia a lábjegyzetekben. ISBN 9789632955155

- A szerkesztők egyetemi oktatók, illetve Koltay András a Médiatanács tagja. A kötet egyike azoknak, amelyek az MTA és az NMHH együttmüködése következtében létrejött Médiatudományi Kutatócsoport eredményeit tanulmányok formájában tartalmazzák. A kutatócsoport célja, hogy a szólás- és sajtószabadság aktuális kérdéseit vizsgálja, hozzájárulva ezzel a magyarországi médiajogi vitákhoz. Jelen kötetben a tanulmányok tematikus szerkezetben, négy nagy szerkezeti egységre osztva szerepelnek. Az első részben a sajtószabadság jogának alapvető kérdéseire és alkotmányos változásaira vonatkozó írások szerepelnek, majd a médiatartalom korlátozásával kapcsolatos elemzések következnek. A harmadik részben a médiaszabályozás közigazgatási jogi aspektusait vizsgáló tanulmányok találhatóak. A kötetet európai uniós és egyéb összehasonlító megközelítésű tanulmányok zárják. (B. É.)

\section{- A politikai szabadságjogok korszakai Magyarországon 1945-től napjainkig} KöBEL Szilvia Gondolat-Állambiztonsági Szolgálatok Történeti Levéltára, Budapest, 2015 Monográfia. Terjedelem: 302. Bibliográfia a lábjegyzetekben és a fejezetek végén. ISBN 9789636936471

- A szerző alkotmányjogász, az Állambiztonsági Szolgálatok Történeti Levéltárának tudományos főmunkatársa, egyetemi oktató. A kötet a politikai szabadságjogok 1945 utáni magyarországi történetét mutatja be. E jogok közé a szerző a lelkiismereti és vallásszabadságot, a szólásszabadságot, a hátrányos megkülönböztetés tilalmát, a szabad mozgás és tartózkodási hely megválasztását, a békés gyülekezéshez és a szabad egyesüléshez való jogokat sorolja. E szabadságjogok közül a szerző leginkább a lelkiismereti és vallásszabadság jogának történeti alakulására, illetve ehhez kapcsolódóan az állam és az egyházak kapcsolatára fókuszál. A további politikai szabadságjogok bizonyos kérdéseit ezekkel összefüggésben vizsgálja. A szólásszabadság, gyülekezési és egyesülési szabadság nyolcvanas évek végi magyarországi alakulását külön fejezetben tárgyalja. (B. É.)

\section{- Free Speech and Censorship Around the Globe}

Péter Molnár (ed.)

CEU Press, Budapest-New York, 2015

Tanulmánykötet. Terjedelem: 552. Bibliográfia a lábjegyzetekben.

ISBN 9789633860564

- A szerkesztő szólásszabadság-kutató a Central European Universityn (Budapest). Az angol nyelvű kötet egyes fejezetei sokszínü megközelítésben vizsgálják a szólásszabadság, és azzal összefüggésben az információszabadság és a médiajog legkülönbözőbb eseteire vonatkozó szabályokat és gyakorlatokat a világ különböző részein és különböző kultúrákban. A vizsgálat célja a szólásszabadsággal 
kapcsolatos fogalmak és a szólás kontextusa jelentőségének feltárása a 20. század második felében és a 21. század elején. A vizsgált időszakban bekövetkezett szóláskorlátozások kritikai olvasatra sarkallták a kötet szerzőit. Az összehasonlító jogi nézőpontú tanulmányok célja, hogy segítsenek az ilyen jellegű visszalépések elkerülésében, és a szólásszabadsággal kapcsolatos gyakorlatok fejlesztésében. A kötet I. részében nemzetközi, áttekintő jellegü, a II. részben a szólásszabadság és az információszabadság érvényesülését, illetve a cenzúra különböző fokú megvalósulását vizsgáló tanulmányok kerültek elhelyezésre. (B. É.)

- Gondolatok névjogról, szólásszabadságról

NAVRATYIL Zoltán

(Sorozat: Médiatudományi Könyvek, ISSN 2064-5597)

MTA Bölcsészettudományi Kutatóközpont, Budapest, 2015

Monográfia. Terjedelem: 120. Bibliográfia: 110-119. és a lábjegyzetekben. ISBN 9789639627970

- A szerző a Pázmány Péter Katolikus Egyetem oktatója. Munkájában arra a kérdésre keresi a választ, hogy az 1959-es, illetve a jelenleg hatályban lévő Polgári Törvénykönyv által személyiségi jogként deklarált névjog, illetve az azzal kapcsolatos jogsérelmek hogyan értelmezhetőek a szólás- és médiaszabadsággal kapcsolatban. Azazhogy a névjog mennyiben korlátozhatja a szólás- és médiaszabadságot, illetve ezzel kapcsolatban vizsgálja az adatvédelem és a magánszféra védelmének egyes aspektusait. A kötetben megvalósul a tárgyalt jogok összehasonlításban történő bemutatása. Az ismertetett - főként magyar, angol, német és egyesült államokbeli - jogesetek átfogó képet adnak számunkra a vizsgált alapjogok érvényesüléséröl a gyakorlatban, bemutatva a különbséget föként az európai és az amerikai joggyakorlat-jogfelfogás között. A kötethez Lábady Tamás írt előszót. (J. V.)

- Alkotmányos alapok

Pozsár-Szentmiklósy Zoltán-Somody Bernadette (szerk.)

Második, átdolgozott kiadás. HVG-ORAC, Budapest, 2015

Egyetemi jegyzet. Terjedelem: 263. Bibliográfia nincs. ISBN 9789632582931

- A szerkesztők és a szerzők egyetemi oktatók. A kötet az ELTE Alkotmányjogi Tanszékének mühelyében a különböző korábbi oktatási anyagok felülvizsgálatával, illetve a 2011-2012-es alkotmányos változásokra tekintettel készült, tananyagként azok számára, akik a felsőoktatásban, de nem jogtudományi képzésben tanulnak alkotmányjogi ismereteket. A kötet első kiadása 2012-ben jelent meg; annak tartalmát ebben az átdolgozott kiadásban aktualizálták a szerzők. A kötet célja, hogy átfogó képet nyújtson az alkotmányos alapelvekről, értékekröl és intézményekről, és ebben a keretben mutassa be a legfontosabb hatályos magyar alkotmányjogi szabályokat. Az első kiadás annotációját lásd a Pro Futuro 2014/1. számában (B. É.) 
- A jogalkalmazás vitatott területei - Vallásszabadság és egyházjog Pribula László (szerk.) Printart-Press, Debrecen, 2015 Konferenciakiadvány. Terjedelem: 166. Bibliográfia a lábjegyzetekben. ISBN 9789638996381

- A szerzők a témakörrel foglalkozó elméleti és gyakorlati szakemberek. A kötet a Debreceni Egyetem Állam- és Jogtudományi Kara és a Debreceni Református Hittudományi Egyetem által szervezett, 2014. október 14-én megrendezett tudományos konferencián elhangzott előadások tanulmánnyá átdolgozott változatait tartalmazza. A tanulmányok jogi és teológiai megközelítésben dolgozzák fel a vallásszabadság és az egyházjog egyes aspektusait, illetve az állam és az egyház kapcsolatára vonatkozó részkérdéseket. Az elméleti megközelítések mellett a gyakorlati szakemberek saját tapasztalatait leíró, illetve az alkotmánybírósági és a rendes bírósági gyakorlatot elemző tanulmányok is megtalálhatóak a kötetben. (B. É.)

- A kínai alkotmány: Zhongguoxianfa

Salát Gergely (szerk.)

(Sorozat: PANTA, ISSN 2416-1438)

Typotex Kft., Budapest, 2015

Tanulmánykötet. Terjedelem: 213. Bibliográfia: 205-214. ISBN 9789632798592

- A szerkesztő egyetemi oktató, kutatási területe az ókori kínai jogtörténet és a modern kínai politika; a szerzők közt sinológusok és jogászok egyaránt szerepelnek. A tanulmánykötet hiánypótló a magyar jogirodalomban, hiszen Kína jogrendszeréröl és alkotmányos berendezkedéséröl mind ez ideig kevés tanulmány jelent meg. A szerzők a kínai alkotmánytörténettel, az alkotmányozás előzményeivel foglalkoznak, valamint az 1982-es, máig hatályban lévő alkotmányt, ezen belül a kínai alkotmányosság alapintézményeit, az igazságszolgáltatás müködését és az emberi jogok és az alkotmányosság kapcsolatát, sajátos kínai megközelítését mutatják be. A kötet a kínai alkotmány hiteles fordítását is tartalmazza. (N. N.)

- Az ügyvédi hivatás alkotmányjogi helyzete

SuLYOK Tamás

(Sorozat: A Pólay Elemér Alapítvány Könyvtára, ISSN 1786-352X; 52.)

Pólay Elemér Alapítvány, Szeged, 2015

Monográfia. Terjedelem: 168. Bibliográfia: 160-165. ISBN 9786155411182

- A szerző alkotmánybíró, korábban két évtizeden át ügyvédként dolgozott. A könyvben az ügyvédi hivatás alkotmányjogi helyzetét vizsgálja, ennek során részletesen foglalkozik az ügyvédi hivatás fejlödésével, bemutatva az angolszász, a francia, a német, a közép-kelet-európai és a magyar fejlödést, külön kitérve a kapcsolódó nemzetközi egyezményekre és az Európai Unió idevonatkozó szabályaira. Bemutat több, az Európai Unió Bírósága által meghozott ítéletet, melyek hozzájárultak az ügyvédi hivatás határok nélkülivé válásához Európa legnagyobb részén. A könyv kiemelten foglalkozik az ügyvédi hivatás alkotmányjogi helyzetével, elhelyezve azt az alkotmányok rendszerében és az Alkotmánybíróság gyakorlatában. (N. E. É.) 
- Tansegédlet az alkotmányjogi záróvizsgához

SzABó Zsolt

(Sorozat: Werbőczy-sorozat, ISSN 2062-2538)

Negyedik, átdolgozott kiadás. Patrocinium, Budapest, 2015

Tansegédlet. Terjedelem: 236. Bibliográfia nincs. ISBN 9789634130437

- A szerző egyetemi oktató. A kötet a Károli Gáspár Református Egyetem alkotmányjogi záróvizsga tételeit alapul véve tartalmazza a felkészülést segítő tananyagot. A tansegédlet az egyes államvizsgatételek vázlatát, lényeges elemeit, a vonatkozó jogszabályokat, alkotmánybírósági határozatokat és egyéb jogforrásokat tartalmazza. A negyedik kiadásban a 2015. szeptember 1-jén hatályos jogszabályi változásokkal frissítette a tételek kidolgozását a szerző, ezáltal segítve a záróvizsgára készülöket. A korábbi kiadás annotációját lásd a Pro Futuro 2016/2. számában. (B. É.)

- Az európai adatvédelmi jog megújitása - Tendenciák és lehetőségek az önszabályozás területén

SzŐKE Gergely László

(Sorozat: Infokommunikáció és Jog Könyvek, ISSN 2060-5021)

HVG-ORAC, Budapest, 2015

Monográfia. Terjedelem: 187. Bibliográfia: 169-187. ISBN 9789632582627

- A szerző egyetemi oktató, a könyv a doktori disszertációjának az átdolgozott változata. Célja, hogy átfogóan bemutassa a személyes adatok védelmével kapcsolatos jogi környezetet. A szerző áttekinti az európai adatvédelmi szabályozás történetét, vizsgálja az európai adatvédelmi jog megújítására vonatkozó reformot és annak eredményeit. Az eredményeket egy általa kialakított új generációs adatvédelmi szabályozási keretrendszerben, kritikus megközelítéssel elemzi. Reflektál az e jogterületen tapasztalt tendenciákból és az adatkezelők kötelezettségeiből fakadó kihívásokra; vizsgálja, hogy az önszabályozás, illetve az adatkezelők belső szabályozása adta változások alkalmasak lehetnek-e a kihívások megoldására. (B. É.)

- Bevezetés az alkotmányjogba - Az Alaptörvény és Magyarország alkotmányos intézményei

Trócsányi László-Schanda Balázs (szerk.)

Negyedik, átdolgozott kiadás. HVG-ORAC, Budapest, 2015

Tankönyv. Terjedelem: 503 . Bibliográfia a lábjegyzetekben és a fejezetek végén. ISBN 9789632582825

- A kötet szerzői a Pázmány Péter Katolikus Egyetem és a Szegedi Tudományegyetem jogi karának oktatói. A hazai alkotmányjog 2010 óta csaknem folyamatos átalakuláson ment keresztül, ami az egyetemi tananyag rendszeres átdolgozását indokolja. Jelen kötet a 2015. augusztus 31-ig megjelent jogszabályi változásokra tekintettel dolgozza fel az ismeretanyagot. A szerzők a hatályos tételes joganyag ismertetése mellett annak alkotmányelméleti szempontból megalapozott bemutatását is megvalósítják. A kötet az alkotmányjogi tanulmányok alkotmányelméleti és államszervezeti részeit tartalmazza, az alapvető jogokkal kapcsolatos kérdéseket nem tárgyalja. A korábbi kiadás annotációját lásd a Pro Futuro 2016/2. számában. (B. É.) 


\section{BÜNÜGYI TUDOMÁNYOK}

\section{- Büntetőjog $I$.}

Balogh Ágnes

(Sorozat: Jogi Szakvizsga Segédkönyvek, 2014-15, ISSN 1417-7986)

Hatodik, jelentősen átdolgozott kiadás. Dialóg Campus, Budapest-Pécs, 2015

Tankönyv. Terjedelem: 279. Bibliográfia: 279. ISBN 979635376566

- A szerző a Pécsi Tudományegyetem jogi karának oktatója, munkája a kiadó által útjára indított jogi szakvizsga segédkönyveknek az anyagi büntetőjog általános részét bemutatni hivatott legújabb, a változásokat tartalmazó, hatályosított darabja. Nemcsak szakvizsgázóknak és joghallgatóknak hasznos, hanem olyan gyakorlati szakembereknek is, akik az elmúlt öt év változásait szeretnék, rendszerbe foglalva áttekinteni. A kötet a jogszabályok megértését a vonatkozó büntető kollégiumi véleményekkel, bírósági döntésekkel és gyakorlati példákkal segíti. A korábbi kiadást annotáltuk a Pro Futuro 2015/2. számában (S. F.)

- Az európai elfogatóparancs Magyarországon - The European Arrest Warrant in Hungary

BÁrd Petra

Országos Kriminológiai Intézet, Budapest, 2015

Monográfia. Terjedelem: 237. Bibliográfia: 219-237. ISBN 9789638946898

- A szerző az Országos Kriminológiai Intézet tudományos főmunkatársa. Művében az európai elfogatóparancsot és általában véve az Európai Unió bünügyi együttműködését elemzi mélyebben. A monográfia két nyelven íródott: elsőként a magyar nyelvű tanulmány olvasható, ezt követi az angol változat. A könyv három részben tekinti át az Európai Unió harmadik pillérének, a bel- és igazságügyi együttmüködésnek a rövid történetét, valamint az elfogatóparancsot. A második részben az elfogatóparancs magyarországi alkotmányos vizsgálatával foglalkozik, a harmadik részben pedig a bünügyi együttmüködésről ír részletesebben, egy esettanulmány keretében. A kötet erénye, hogy üzenetet hordoz az európai igazságszolgáltatási térség jövőbeli alakulása iránt érdeklődők számára is, a bizalom erősítésének lehetőségeivel kapcsolatban. (H. D.)

\section{- Nemzetek feletti büntetőjog az Európai Unióban}

BÉKÉs Ádám

HVG-ORAC, Budapest, 2015

Monográfia. Terjedelem: 458. Bibliográfia: 446-458. ISBN 9789632582870

- A szerző egyetemi adjunktus a Pázmány Péter Katolikus Egyetemen. A monográfiát hét fejezetre osztotta: ír az európai jogról általánosságban; boncolgatja az európai büntetőjog fogalmát; áttekinti az Unió büntetőpolitikájának fejlődését; a bűnügyi együttműködést szolgáló fontosabb intézményeket; ismerteti az Európai Bíróság jogfejlesztő munkáját; valamint az Emberi Jogok Európai Bírósága gyakorlatának egyes aspektusait; végezetül a zárszóban foglalja össze gondolatait. A könyv jelentősége, szemben a témában keletkezett hasonló müvekkel, abban áll, hogy már a Lisszaboni Szerződést követően, a megváltozott jogi környezet- 
ben íródott; a szerző feltárja az Európai Unió sajátos felépítéséből és működési rendszeréből eredő jellegzetességeket, bemutatva a közösségi jog fejlödésének a büntetőjogra gyakorolt hatását. (H. D.)

- Büntető eljárásjog

BeLovics Ervin-Tóth Mihály

Második, aktualizált kiadás. HVG-ORAC, Budapest, 2015

Tankönyv. Terjedelem: 607. Bibliográfia: 605-607. ISBN 9789632582849

- A szerzők egyetemi tanárok, illetve Belovics Ervin a legföbb ügyész büntetőjogi helyettese. A kötet második, aktualizált kiadás, mely szerkezetében is és tartalmában is több ponton eltér az első, 2013-as kiadástól. A tartalmi változtatást elsősorban a megjelenést követően hatályba lépett szabályok eredményezik, hiszen a mű elsődleges célja, hogy ezek alapján dolgozza át a korábban kiadott tankönyv megállapításait. A 18 fejezetben ismertetett tananyag elsősorban az egyes jogintézmények lényegi elemeinek bemutatására törekszik, emellett egy jól áttekinthető rendszerben nyújt segítséget a jogalkalmazók számára. A korábbi kiadást annotáltuk a Pro Futuro 2015/1. számában. (Sz. Zs.)

\section{- Büntetöjog: Különös Rész I-II.}

Blaskó Béla-Hautzinger Zoltán-Madal Sándor-Pallagi Anikó-Polt Péter-Schubauer László

Átdolgozott kiadás. Rejtjel, Budapest-Debrecen, 2015

Egyetemi jegyzet. Terjedelem: 469 (I. kötet), 466 (II. kötet). Bibliográfia nincs. ISBN 9789637255922 (I. kötet), 9789637255953 (II. kötet)

- A szerzők a Nemzeti Közszolgálati Egyetem, illetve a Debreceni Egyetem oktatói. A tankönyv újabb kiadását a Btk. módosításai tették indokolttá. A könyv a büntetőjog különös részének tényállásait tartalmazza, fejezetei a Btk. szerkezeti felépítéséhez igazodnak. Az I. kötet a Btk. XIII. fejezetétöl a XXIX. fejezetéig, a II. kötet a Btk. XXX. fejezetétöl a XLV. fejezetéig szereplő büncselekmények tényállásait tekinti át. A kötet az előző kiadásokban megismert logika szerint épül fel. Tagolása és szerkesztése jól követhetővé teszi. A büncselekmények aprólékos és szakmailag is részletes elemzése miatt nemcsak a büntetőjoggal ismerkedő joghallgatók számára nyújthat hasznos segítséget a büntetőjog különös részének mélyebb elsajátításához, de hasznos kézikönyv lehet a büntetőjoggal már régebben foglalkozó elméleti és gyakorlati szakemberek számára is egy-egy felmerülö büntetőjogi probléma megoldásához. Az előző kiadás annotációját lásd a Pro Futuro 2015/1. számában. (H. D.)

- Magyar büntetőjog: általános részi ismeretek

CsemÁné VÁRAdI Erika-GörgénYI llona-Gula József-Jacsó Judit-LéVAY MiklósSÁNTHA Ferenc

Miskolci Egyetemi Kiadó, Miskolc, 2015

Egyetemi jegyzet. Terjedelem: 242. Bibliográfia nincs. ISBN 9786155216770

- A Miskolci Egyetem tapasztalt oktatóinak újabb kötete a Magyar büntetőjog: általános részi ismeretek, mely a Miskolci Egyetem más tankönyveihez hasonló dog- 
matikai és metodikai alapossággal dolgozza fel a címben szereplő tárgyat. Terjedelme ugyanakkor szükebb. Nem joghallgatók, hanem a büntetőjoggal kisebb mélységben foglalkozók számára nyújt pontos, jól használható, kompakt ismereteket. Hasznos lehet ugyanakkor a büntetőjoggal foglalkozók számára is, mint olyan kötet, amely gyors áttekintést tesz lehetővé a közelmúltban bekövetkezett változásokról. (S. F.)

- Antikorrupció és integritás

Dargay Eszter-Juhász Lilla Mária (szerk.)

Nemzeti Közszolgálati Egyetem, Budapest, 2015

Konferenciakiadvány. Terjedelem: 201. Bibliográfia a fejezetek végén. ISBN 9786155527623

- A szerzők egyetemi oktatók és gyakorló jogászok, a Belügyminisztérium és a Nemzeti Védelmi Szolgálat munkatársai. A kötet a 2015. december 10-én, Budapesten megrendezett konferencia szerkesztett anyaga. A tanulmányok általános képet adnak az integritás és az antikorrupció témaköréröl. A könyv bemutatja a nemzetközi törekvéseket és eredményeket, elemzi az OECD-jelentéseket, és ismerteti az Európai Unió jelenlegi stratégiáját. Emellett az olvasó betekintést nyerhet a magyar antikorrupciós küzdelembe is: a Nemzeti Védelmi Szolgálat szerepétöl és müködésétől kezdve a korrupciós bűncselekményekig számtalan témát felölelnek a kiadvány írásai. A tanulmánykötetet angol nyelvü összefoglalók zárják. (H. D.)

- Büntető anyagi jog I-IV. az új Btk. alapján

Deres Petronella-Domokos Andrea

Második, átdolgozott kiadás. Patrocinium, Budapest, 2015

Egyetemi jegyzet. Terjedelem: 222 (I. kötet), 150 (II. kötet), 142 (III. kötet), 89 (IV. kötet). Bibliográfia a lábjegyzetekben. ISBN 978963413016 (I. kötet), 978963 4130185 (II. kötet), 9789634130215 (III. kötet), 9789634130222 (IV. kötet)

- A szerzők egyetemi oktatók. A jegyzet az első kiadás hatályosított, átdolgozott változata. Elsősorban joghallgatóknak ajánlott, hiszen a büntetőjogi vizsgára, záróvizsgára való felkészülést segíti elő. Szerkezetét tekintve a Büntető Törvénykönyvröl szóló 2012. évi C. törvény (Btk.) felépítését követi; a törvényszöveget idézi, ezt követően írja le a vonatkozó elméleti ismereteket, illetve elemzi az esetlegesen felmerülő, releváns gyakorlati kérdéseket. A jegyzet első része a szándékosság és gondatlanság kérdéskörének szentelt fejezettel egészült ki, a korábbi kiadáshoz képest, illetve a bemutatás sorrendje módosult. A 2013-as kiadásnál a II. kötet még az egyes különös részi tényállásokkal foglalkozott; a késöbbiek során a II. kötet az Általános Részre korlátozódott. Apróbb kiegészítések jelennek meg itt és a Különös Részt vizsgáló, további kötetekben is. A korábbi kiadást annotáltuk a Pro Futuro 2015/2. számában. (A. Zs.) 
- Vadászok, halászok a büntetőjog hálójában

ELEK Balázs

HVG-ORAC, Budapest, 2015

Monográfia. Terjedelem: 325. Bibliográfia: 319-325. ISBN 9789632582726

- A szerző bíró, a Debreceni Egyetem oktatója. E munkájával segítséget kíván nyújtani a büntetőjogi és egyéb szakirányú előirások megismeréséhez, ezáltal hozzájárulva a vadászat körében előforduló balesetek csökkentéséhez, a bűncselekmények visszaszorításához. Mindezeket a szerző színes, a valóságban megtörtént esetek bemutatásán és a bírói gyakorlat által kimunkált, avagy éppen kialakulóban lévő megoldások ismertetése útján törekszik elérni. Mindvégig szem előtt tartja azon célkitűzését, hogy mind az elkövetöket, mind másokat visszatartson a tanulmányban szép számmal felvonultatott, és a témában szóba jöhető bűncselekmények elkövetésétöl. A monográfia nem csupán a jogásztársadalom, hanem a vadászattal, halászattal és horgászattal kapcsolatba kerülök, de általában a természet és a sport iránt érdeklődők számára is haszonnal forgatható. (L. B.)

- Úton a bírói meggyőződés felé: a készülő büntetőeljárási törvény kodifikációja Elek Balázs-Miskolczi Barna (szerk.)

Printart-Press, Debrecen, 2015

Konferenciakiadvány. Terjedelem: 256. Bibliográfia a lábjegyzetekben. ISBN 9789638996367

- A tanulmánykötet az Igazságügyi Minisztérium, valamint a Debreceni Egyetem Állam- és Jogtudományi Kara közös szervezésében, 2014. december 12-én megrendezett konferencia szerkesztett anyaga. A könyvet különösen értékessé teszi, hogy különböző hivatásrendbeli, gyakorlati szakemberek fogalmaznak meg elvárásokat az új törvénnyel szemben. A kötet bemutatja a büntetőeljárási törvény aggályos területeit, valamint a készülő törvény változtatásainak föbb irányvonalait is. A 16 rövidebb tanulmány között számos PhD-hallgató előadásának az írásos változata is megtalálható, melyek szintén szorosan a kodifikációhoz kapcsolódó eredményeket ismertetnek. (Sz. Zs.)

- Büntetö eljárásjog I-II.

FANTOLY Zsanett-BudAHÁZY Árpád

Nemzeti Közszolgálati Egyetem, Budapest, 2015

Tankönyv. Terjedelem: 271 (I. kötet), 269 (II. kötet). Bibliográfia: 251-257 (I. kötet), 203-208 (II. kötet). ISBN 9786155527050 (I. kötet), 9786155527630 (II. kötet)

- A szerzők a Nemzeti Közszolgálati Egyetem Rendészettudományi Karának oktatói. A tankönyv a büntető eljárásjogot tanuló hallgatók, valamint a téma iránt érdeklődők számára készült; első kötete a büntetőeljárási törvény statikus részét, második kötete pedig a büntetőeljárási törvény dinamikus részét mutatja be, követve a kódex felépítését. A kiadvány nem csupán a tételes joganyag dogmatikailag rendszerezett ismertetését tartalmazza, hanem a vonatkozó nemzetközi és hazai bírói gyakorlat, és a jogtudományi álláspontok feltüntetésével is törekszik segítséget nyújtani a hallgatóknak a komplex tudás elsajátításához. A jogesetek és az iratminták emellett a gyakorlati jogi ismeretek megszerzését is biztosítják. (L. B.) 
- A környezet és természet elleni büncselekmények nyomozása FARKASNÉ DR. HaLÁsz Henrietta Nemzeti Közszolgálati Egyetem Rendészettudományi Kar, Budapest, 2015 Egyetemi jegyzet. Terjedelem: 111. Bibliográfia: 107-111. ISBN 9786155527074

- A szerző egyetemi oktató. Célja a tananyagalkotáson túl az is, hogy a témáról való gondolkodás egységesítése és javítása irányában hasson. Az előszót követően a jogi szabályozást és intézményrendszert mutatja be, így az alkotmányjogi alapokat, az európai uniós szabályozást, a környezet-, és természetvédelmi szervezetrendszert, valamint a büntetőjogi és a szabálysértési jogi hátteret. A további fejezetek a természetkárosítás nyomozását, az államhatárhoz kötődő elkövetési magatartásokat, a környezetkárosítás, a hulladékgazdálkodás rendjének megsértése büncselekmény, valamint az állatkínzás nyomozását ismertetik. A jegyzet az újonnan bevezetett orvvadászat és orvhalászat tényállásait is elemzi, és a téma alapos bemutatása érdekében mellékletként tartalmazza a legfontosabb iratmintákat és vonatkozó rendeleteket. (T. A. N.)

- Büntetőjog: általános rész

Filó Mihály (szerk.)

(Sorozat: ELTE Jogi Kari Jegyzetek, ISSN 2060-5986; 19.)

ELTE Eötvös Kiadó, Budapest, 2015

Jegyzet. Terjedelem: 219. Bibliográfia nincs. ISBN 9789633122358

- A szerkesztő az Eötvös Loránd Tudományegyetem Állam- és Jogtudományi Karának oktatója. A könyv a kar igazságügyi ügyintéző alapszakának hallgatói részére készült. Igazodva a szak sajátos képzési igényeihez, a büntetőjog általános részének két kiemelt témájára fektet nagyobb hangsúlyt. Így elsőként a felelősségtan és a büntetéstan alapvető kérdéseit ismerteti részletesen, ezt követően a nemzetközi büntetőjog témakörét elemzi, melynek során kifejezetten a magyar vonatkozású esetekre koncentrál, és tesz megállapításokat. (H. D.)

- Bünmegelőzés-alapú társadalom: prevenció a XXI. században.

GaRAMVÖLGYı László

Studium Plusz, Budapest, 2015

Monográfia. Terjedelem: 496. Bibliográfia: 483-491. ISBN 9786155463839

- A rendőrségi szóvivőként ismertté vált szakember a napjainkra nagymértékben átalakult bűnözésre és a bünözés új kihívásaira keresi a választ, elsősorban a bünmegelőzés-alapú társadalom modellezésével. A müben olyan aktuális kérdésekre tér ki, mint a közbiztonság, a globalizáció, a politika és bünözés kapcsolata és a „zombiapokalipszis” újraértelmezése. Ezekkel a témákkal kapcsolatosan a kriminalitás különböző aspektusait tárgyalja, többek között azt, hogy a globalizációnak mi lehet a szerepe a kriminalitással összefüggésben. Sokrétü, komplex szemléletmód és megközelítés jellemzi, kitér a gazdasági ciklusok, a devianciák, a maffia, a bibliai elemek, az ókori történelem, az orosz politika, az amerikai elnökök, továbbá a média kriminalitásban betöltött szerepére is. (A. Zs.) 
- Magyar büntetöjog: Különös Rész

GörgénYI llona-Gula József-Horváth Tibor-Jacsó Judit-LÉvay Miklós-Sántha Ferenc-VÁRADI Erika

Átdolgozott kiadás. CompLex, Budapest, 2015

Tankönyv. Terjedelem: 716. Bibliográfia: 709-716. ISBN 9789632953519

- A könyv szerzői a Miskolci Egyetem Büntetőjogi és Kriminológiai Tanszékének munkatársai. A legújabb kiadás az időközben bekövetkezett jogszabályi és ebböl fakadó jogalkalmazói változásokat jeleníti meg, az - időközben elhunyt - Horváth Tibor nevével (is) fémjelzett, méltán népszerü kötetben. A témához igazodva a fejezetek a Btk. fejezeteit követik. Minden fejezet elején jogtörténeti és jogelméleti áttekintés vezeti be az olvasót, ezt követően kerül sor az egyes tényállások részletes bemutatására. $A$ kötet egyebekben hüen követi az előző kiadásokban megismert felépítést, az egyes témakörökhöz kapcsolódó gyakorlat $(\mathrm{BH}-\mathrm{k}$, kúriai döntések, kollégiumi vélemények, jogegységi határozatok) ismertetésével. Az elöző kiadást annotáltuk a Pro Futuro 2016/1. számában. (S. F.)

- Gályapadból laboratóriumot - Tanulmányok Finszter Géza professzor tiszteletére Hack Péter-Király Eszter-Korinek László-Patyi András (szerk.)

ELTE Eötvös Kiadó, Budapest, 2015

Tanulmánykötet. Terjedelem: 518. Bibliográfia a lábjegyzetekben.

ISBN 9789633122259

- A kötet Finszter Géza nyugalmazott rendőr ezredes, egyetemi tanár tiszteletére, 70. születésnapja alkalmából készült, szerzői ennek megfelelően az ünnepelt tanítványai, barátai, pályatársai. Első része rendészeti témájú, a második büntetőjogi tárgyú, a harmadik rész pedig a kriminológia területéhez tartozó, magas szakmai színvonalú értekezéseket vonultat fel. A negyedik rész egy válogatást ad Finszter Géza közírói munkásságából. Az Utóhang c. fejezet tartalmazza a professzor publikációs jegyzékét. $A$ kötet a nagyrészt magyar nyelvü tanulmányokon kívül egy francia nyelvű esszét is tartalmaz. (H.D)

- Kriminalisztikatörténeti tanulmányok

IBOLYA Tibor

Patrocinium, Budapest, 2015

Tanulmánykötet. Terjedelem: 174. Bibliográfia a lábjegyzetekben.

ISBN 9789634130079

- A szerző egyetemi oktató, ügyész. Hét tanulmányában szemléletesen és olvasmányosan, korabeli rajzokat és fényképeket is mellékelve mutatja be a tetoválást mint a kriminalisztikai azonosítás eszközét. Megismerteti továbbá az olvasót az első magyar kriminalisztikai tankönyvvel és szerzőjével, Endrődy Gézával, valamint Gábor Bélával, a daktiloszkópia első magyar szakértőjével. Ezen túlmenően lebilincselő stílusban tér ki az 1907-es, híres dánosi rablógyilkosság korabeli szakirodalmára, az 1908-as első magyarországi bankrablásra, Mágnás Elza meggyilkolására és Szojka Párnó bűnöző életére. Az izgalmas, jól felépített kötet ajánlható a jogtudomány képviselöinek, a gyakorló jogászoknak, de a témával behatóbban ismerkedni kívánó joghallgatóknak és laikus állampolgároknak is. (H. T.) 


\section{- Megbüntethetetlen bünök}

IRK Ferenc

Bíbor, Miskolc, 2015

Monográfia. Terjedelem: 236. Bibliográfia: 189-210. ISBN 9786155536106

- A szerző jogász, kriminológus. A monográfia a transznacionális gazdálkodó szervezetek kockázatmenedzselését tekinti át sajátos szemmel. Hét fejezetben, széleskörűen foglalkozik a vállalatok kockázatelemzésével, felelősségi kérdéseivel, a devianciákkal, illetve a gazdálkodó szervezetek bűnözésével. Az utóbbi témakörön belül részletesen elemzi a büntetőjogi aspektusokat, kitér a szervezeti bünözésre, a vállalati bünözésre, illetve olyan büncselekményeket mutat be, amelyeket a munkavállalók követhetnek el, és amelyeknek áldozatai lehetnek. A szerző külön fejezetet szán az egyes iparágakon (autóipar, ruhaipar, élelmiszeripar stb.) belül elkövethető büncselekmények elemzésére. (A. Zs.)

\section{- Büntetés-végrehajtási jog}

JuHÁsz Zsuzsanna-LőrinCZ József

(Sorozat: Fundamenta Fontium Juris Criminalis, ISSN 2064-3462)

lurisperitus Bt., Szeged, 2015

Tankönyv. Terjedelem: 278. Bibliográfia a fejezetek végén. ISBN 9786155411298

- A szerzők a Szegedi Tudományegyetem Állam- és Jogtudományi Karának oktatói. A kötet a szegedi büntetőjogi iskola könyvsorozata, mely az újrakodifikált büntetés-végrehajtási jog rendszertanát, sajátosságait és gyakorlatát a tantárgyi felosztást követve, öt nagyobb fejezetben mutatja be, melyek a következők: a büntetés-végrehajtási jog; a szabadságelvonással járó büntetések, a szabadságelvonással járó intézkedések és kényszerintézkedések végrehajtása; a szabadságelvonással nem járó jogkövetkezmények végrehajtása, illetve a büntetés-végrehajtás jogállami kontrollrendszere. A könyv igazi különlegessége, hogy a problémafelvető kérdések mellett, az egyes fejezetek elején ismertetett jogeseteken keresztül mutatja be az adott témakört, érdekesebbé és érthetöbbé téve ezzel az elsajátítandó tananyagot. (Sz. Zs.)

\section{- Alapelvi (r)evolúció az európai büntetőjogban}

Karsal Krisztina

Pólay Elemér Alapítvány, Szeged, 2015

Monográfia. Terjedelem: 191. Bibliográfia: 178-188. és a lábjegyzetekben. ISBN 9786155411250

- A szerző egyetemi tanár, akinek a tollából született, az európai büntetőjoggal foglalkozó számos munka már sorozatnak tekinthető. Újabb műve ezúttal az alapelvek oldaláról közelíti meg a tárgykört. A vizsgálódás fókusza a magyar büntetőjogi alapelvek változása az európai jogi fejlődés eredményeképpen. Az alapvetést és a fogalmak tisztázását követően, először a klasszikus büntetőjogi alapelveket elemzi, úgymint az anyagi jogi legalitást, a bünösségen alapuló felelősség elvét és a büntetőjog ultima ratio jellegét és szubszidiaritását. Ezt követően az európai büntetőjogi elvek elemzése következik, feltárva azok részletes jelentését, érvényesülésének jellemzőit, esetleges alkalmazási nehézségeit. A munka magas 
szakmai színvonala, a téma aktualitása, a jogintézmények megfelelő elméleti keretbe foglalása, ugyanakkor a gyakorlati nehézségek feltárása, és a szerzőtől már megszokott élvezetes stílus teszi még érdekesebbé az olvasást. (P. T. Á.)

- Az egészségügyi beavatkozás és kutatás rendje elleni büncselekmények, valamint az egészségügyi önrendelkezési jog megsértése

KovÁcs Gábor

Universitas-Győr, Győr, 2015

Monográfia. Terjedelem: 303. Bibliográfia: 283-303. ISBN 9786155298769

- A szerző a Széchenyi István Egyetem Deák Ferenc Állam- és Jogtudományi Kar oktatója. A mü hiánypótlónak tekinthető a magyar büntetőjog szakirodalmában. Az általános áttekintés keretében alapvető fogalmakat tisztáz, részletesen foglalkozik a bioetika témájával, a jog és a kriminalizáció kapcsolatával, a bioetikai tárgyú nemzetközi kodifikációval, a hazai bioetikai tárgyú alkotmányos jogvédelemmel és az alkotmánybírósági gyakorlattal. Ezt követően bemutatja és elemzi az egyes témához kapcsolódó tényállásokat. A könyv a szélesebb körű jogásztársadalom és az orvostudomány mủvelői számára is értékes olvasmány. ( $A$. Zs.)

- Dobos-könyv - Emlékkönyv Dr. Dobos János születésének 80. évfordulója tiszteletére

Kovács Gyula (szerk.)

Patrocinium, Budapest, 2015

Tanulmánykötet. Terjedelem: 223. Bibliográfia a lábjegyzetekben.

ISBN 9789634130239

- Az ünnepi kötet Dobos János rendőr ezredes, szakíró, föiskolai oktató tiszteletére, a 80. születésnapja alkalmából jelent meg. A szerzők neves rendőrségi szakemberek. A kötet bemutatja Dobos János életpályáját, három bünügyi jellegű cikkén keresztül bepillantást nyújt munkásságába, és tartalmazza a pályatársak visszaemlékezéseit is. A könyv jogi vonatkozású részében öt tanulmányt olvashatunk, amelyek egy-egy témát a bünüldözés szempontjából mutatnak be. Átfogó képet kapunk a betöréses lopás megjelenési formáiról, a rablás forrónyomos felderítésének feltételeiről, továbbá a sértetti közrehatás jelentőségéről, kérdőíves kutatás módszerén keresztül. Áttekinti továbbá a kábítószerrel kapcsolatos būncselekmények bủnüldözése során használt módszereket, valamint a tanúvédelem magyarországi szabályozását is. A kötetet bűnügyi történetek és illusztrációk is színesítik. (F. V. Z.)

- A korrupció

KöHALMı László

(Sorozat: Acta Criminalia, ISSN 1786-6758; 2.)

PTE ÁJK Gazdasági Büntetőjogi Kutatóintézet, Pécs, 2015

Kismonográfia. Terjedelem: 107. Bibliográfia a fejezetek végén.

ISBN 9789636428372

- A szerző a PTE ÁJK oktatója. Kötetében a kriminálpolitika egyik legjelentősebb kérdésével, a korrupcióval foglalkozik részletesen. Arra keresi a választ, hogy ho- 
gyan lehet eredményesebben fellépni a korrupció ellen. Ennek érdekében, egy történeti bevezetést követően, bemutatja a korrupció természetét, a jog és az etika korrupció-visszaszorító erejét. Ezt követően az önvédelmi korrupció koncepciójával foglalkozik, majd az üzleti szektorban jelentkező korrupció megelőzésére tesz javaslatokat. Végezetül pedig egy empirikus kutatás eredményeit ismerteti. A szerző a témával kapcsolatosan egy kérdéssort állított össze, amelyet 100 joghallgatóval töltetett ki, és amellyel arra kereste a választ, hogy a jövő jogalkalmazói, bűnüldözői vagy éppen védői, miként vélekednek a korrupcióról. (P. G.)

- Szabadulás a büntetés-végrehajtási intézetböl

Nagy Anita

Bíbor, Miskolc, 2015

Monográfia. Terjedelem: 274. Bibliográfia a lábjegyzetekben.

ISBN 9789155536120

- A szerző a Miskolci Egyetem oktatója. A kötet a büntetés-végrehajtási jog témakörén belül az elítéltek azon szabadulási formáit mutatja be, amikor a tényleges szabadságvesztés letöltését megelőzően szabadulnak. Ennek megfelelően tudományos igényességgel taglalja a kegyelmi eljárás, a reintegrációs őrizet, a feltételes szabadságra bocsátás mint szabadulási formák feltételeit, eljárását, jellegzetességeit, és egyben nemzetközi kitekintést is nyújt az egyes jogintézmények vonatkozásában. A büntetés-végrehajtási intézetek túlzsúfoltságának problematikájából kiindulva vázolja fel a jövő lehetséges útjaként a sikeres reintegrációt. A kötetet különösen értékessé teszik a szerző empirikus kutatási tapasztalatai. (F. V. Z.)

\section{- Az ügyész diszkrecionális jogköre}

\section{Róth Erika}

Miskolci Egyetemi Könyvkiadó, Miskolc, 2015

Monográfia. Terjedelem: 215. Bibliográfia: 201-215. ISBN 9786155216916

- A szerző egyetemi oktató, ügyvéd. A könyv az ügyész mérlegelési jogkörét az alkotmányos büntetőeljárási követelmények, a nemzetközi elvárások, valamint egyes európai országok gyakorlata alapján teszi vizsgálatának tárgyává, melynek során külön figyelmet szentel a készülő új büntetőeljárási törvény koncepcionális elveinek is. Kiemeli, hogy a diverziós eszközök optimális alkalmazása a terhelt és a sértett érdekeit szolgálja, egyúttal maga után vonja a bíróság munkaterhének csökkenését is. Monográfiájában összeveti a vádhatóság egyre szélesedő elterelési lehetőségét a bíróság igazságszolgáltatási funkciójával, elemezve az ügyész quasi bírói hatáskörrel történö felruházását, a döntését befolyásoló körülmények megismerhetőségét, eljárása átláthatóságát, valamint számonkérhetőségét. (L. B.)

- Korszakváltás a büntetés-végrehajtásban: útmutató a 2013. évi CCXL. (BV.) törvény megismeréséhez.

Schmehl János-Pallo József (szerk.)

(Sorozat: Börtönügyi Tanulmányok, ISSN 2064-5457; 2.) 
Büntetés-végrehajtás Tudományos Tanácsa, Budapest, 2015

Kézikönyv. Terjedelem: 179. Bibliográfia: 158-162. ISBN 9789638999634

- A mü szerkesztői a Büntetés-végrehajtás Országos Parancsnokságának tagjai. Jelen kötet az Országgyülés által 2013. december 17-én elfogadott büntetések, az intézkedések, egyes kényszerintézkedések és a szabálysértési elzárás végrehajtásáról szóló 2013. évi CCXL. törvény legfontosabb részeit mutatja be. A könyvet egyben szakmatörténeti dokumentumnak is szánták, figyelembe véve a jogterület dinamikus változásának lehetőségét. A kötet a modern kori magyar büntetés-végrehajtási jog kodifikációs csomópontjain, valamint az európai jogi környezet ismertetésén túl kommentárként nyújt segítséget a jogalkalmazók számára. (Sz. Zs.)

- Alkotmány és anyagi büntetőjog - A büntetőjog-alkalmazás alkotmányosságának egyes kérdései

SzOMORA Zsolt

Pólay Elemér Alapítvány, Szeged, 2015

Monográfia. Terjedelem: 151. Bibliográfia: 124-148. és a lábjegyzetekben.

ISBN 9786155411267

- A szerző a Szegedi Tudományegyetem docense. A büntetőjog alkotmányosságának kérdése viszonylag új keletű a magyar büntetőjogban, összefoglaló monográfia ebben a témában még eddig nem jelent meg. A könyv első részében az alkotmányos büntetőjogi garanciák rendszerét tekinti át a szerző. Ezt követően kerül sor a büntetőjog-alkalmazás alkotmányossági kérdéseinek feltárására, ezen belül részletesen bemutatásra kerül a teleologikus és az alkotmánykonform normaértelmezés. A mü jelentős részét képezi a becsület mint jogi tárgy, valamint a rágalmazási és becsületsértési büntetőítéletek elemzése. Kritikai elemzés tárgya továbbá a büntetőítéletet első ízben megsemmisítő alkotmánybírósági határozat, amelyik szintén a véleménynyilvánítás szabadságához kapcsolódik. Majd további esetjogelemzés zárja a könyvet, az alkotmányos norma büntetőbírósági alkalmazásának tapasztalatait és problematikus pontjait tárva fel. (P. T. Á.)

- Budapest - Prostitúció - A fövárosi utcai prostitúció rendészeti szempontú vizsgálata TAMÁsı Erzsébet

Országos Kriminológiai Intézet, Budapest, 2015

Monográfia. Terjedelem: 171. Bibliográfia: 157-163. ISBN 9789637373213

- A szerző a PPKE JÁK oktatója, illetve az Országos Kriminológiai Intézet tudományos főmunkatársa. Monográfiájában arra vállalkozott, hogy komplex képet adjon a fővárosi prostitúció volumenéről, illetve megjelenési formáiról. Ennek érdekében számos interjút készített a prostituáltakkal és a velük foglalkozó civilszervezetekkel, valamint áttekintette a kerületi rendőrségek prostitúcióval kapcsolatos tevékenységét is. Végezetül a kutatás a Budapest utcáin zajló prostitúció rendészeti kezelésének megismerésére, valamint az ezzel kapcsolatos szabálysértésekre és bűncselekményekre, továbbá a prostitúciót végző nők helyzetére koncentrálódott, alapvetően rendészeti szempontból. A téma feldolgozásának újdonsága és komplex megközelítése miatt egyéb társadalomtudományok művelői, a szociológia, pszichológia iránt érdeklődők számára is érdekes olvasmány lehet. (P. G.) 


\section{EURÓPA-JOG ÉS NEMZETKÖZI JOG}

- Decem anni in Europaea Unione II. - Európai és nemzetközi jogi tanulmányok Angyal Zoltán (szerk.)

(Sorozat: Miskolci Jogtudományi Mühely, ISSN 1589-1518; 7.)

Miskolci Egyetemi Kiadó, Miskolc, 2015

Tanulmánykötet. Terjedelem: 162. Bibliográfia a lábjegyzetekben. ISBN 9786155216787

- A szerzők egyetemi oktatók, PhD-hallgatók. A kötet a miskolci jogi kar Európai és Nemzetközi Jogi Intézete által, Magyarország Európai Uniós csatlakozásának 10. évfordulója alkalmából szervezett konferencián elhangzott előadások anyagát tartalmazza. A változatos témákkal foglalkozó kötetben olvashatunk többek között a határokon átnyúló büncselekmények elleni uniós küzdelemröl, a büntetőjogi és kollíziós magánjogi jogegységesítés kérdéseiröl vagy a kulturális jogok nemzetközi védelméröl. Kiemelt szerepet kap a nemzetközi családjog problémaköre, a közreadott kilenc tanulmányból ugyanis három e területtel foglalkozik. A kötet teljes terjedelmében elérhető elektronikusan a Miskolci Egyetem honlapján. (Sz. D.)

- Nemzetközi szerződések mozgásban - Alkotmányos és nemzetközi jogi kihívások az Európai Unió külkapcsolataiban

BARTHA Ildikó

Dialóg Campus, Budapest-Pécs, 2015

Monográfia. Terjedelem: 303. Bibliográfia: 285-303. ISBN 9786155376726

- A szerző egyetemi oktató. Kötetében az Európai Unió nemzetközi szerződéses kapcsolatrendszerén keresztül vizsgálja az Unió külkapcsolatainak fejlödését, annak sajátos dinamikáját. Részletesen foglalkozik az Európai Unió alkotmányosodásának kérdéskörével, majd ennek tükrében mutatja be az alapszerződések külkapcsolatokra vonatkozó rendelkezéseit, illetve a beleértett külső hatáskörök doktrínáját. Különös figyelmet fordít az uniós jog és a nemzetközi jog kapcsolódási pontjainak, illetve a tagállamok és az Unió nemzetközi szerződései müködésének vizsgálatára az integráció olyan kulcsfontosságú területein, mint a közös kül- és kereskedelempolitika, illetve a légi közlekedés. (Sz. D.)

- A nem állami szereplök elleni önvédelem a nemzetközi jogban

KaJTÁr Gábor

(Sorozat: ELTE Jogi Kari Tudomány, ISSN 2060-9361; 29.)

ELTE Eötvös Kiadó, Budapest, 2015

Monográfia. Terjedelem: 561. Bibliográfia: 486-532. ISBN 9789633122266

- A szerző az ELTE jogi karának oktatója, kötete a 2014-ben megvédett doktori értekezése alapján született. A munka részletesen bemutatja a nem állami szereplők, így elsősorban a terrorszervezetek által elkövetett fegyveres támadások állami magatartásként történő betudásának kérdését, valamint az ezekkel szembeni önvédelem jogalapjára vonatkozó föbb elméleteket. Azt is vizsgálja, hogy a 2001. szeptember 11-i terrortámadás és az USA válaszpolitikája milyen hatással volt a háborúindítás tilalmára, illetve az e tilalom alóli egyik kivételnek tekinthető 
önvédelem jogának gyakorlására. A kötet a Jogtudományi Intézet által alapított Pro Dissertatione luridica Excellentissima Díj első nyertese volt. (B. M.)

- Nemzetközi jog

Kardos Gábor-Lattmann Tamás (szerk.)

(Sorozat: ELTE Jogi Kari Tankönyvek, ISSN 2060-6494; 3.)

ELTE Eötvös Kiadó, Budapest, 2015

Egyetemi tankönyv. Terjedelem: 497. Bibliográfia: 477-479. ISBN 9789633120224

- A2010-es kiadás változatlan utánnyomása. Annotációját lásd a Pro Futuro 2012/1. számában. (B. M.)

\section{- Bevezetés az Európai Unió politikáiba}

Kende Tamás (szerk.)

Negyedik, átdolgozott kiadás. Wolters Kluwer, Budapest, 2015

Tankönyv. Terjedelem: 954. Bibliográfia: 937-954. ISBN 9789632954608

- A szerzők egyetemi oktatók és gyakorló jogászok, közgazdászok, diplomaták. A kötet célja, hogy átfogó képet adjon az Európai Unió legfontosabb - horizontális és ágazati - politikáiról. Az egyes fejezetek kitérnek az adott uniós politika megjelenésére, célkitǔzéseire, lényeges sajátosságaira, és bemutatják az egyes területek legfontosabb jogszabályait, jogszabály-tervezeteit és szabályozási koncepcióit. Önálló fejezet foglalkozik az uniós politikák és politikaformálási folyamat általános sajátosságainak bemutatásával. A fejezetek egységes felépítése, a táblázatok, térképek és ismétlő kérdések, valamint a részletes tárgy-, jogeset- és jogforrásmutató a kötet nagy terjedelme mellett is biztosítja annak könnyü kezelhetőségét. (Sz. D.)

\section{- A legújabb kori népvándorlás: a migráció és az iszlám Európában}

\section{KondoRosı Ferenc}

Magyar Önkormányzatok Szövetsége, Budapest, 2015

Tanulmánykötet. Terjedelem: 150. Bibliográfia a lábjegyzetekben. ISBN 9789631234756

- A szerző egyetemi oktató. Munkájának célja segítséget nyújtani a legújabb kori népvándorlás jelenségének, az azt övező vitáknak a megértéséhez. Elsőként a migráció történelmi és társadalmi kontextusát vázolja fel, majd az iszlám vallás terjedésével felvetődő emberi jogi kérdéseket tárgyalja, például a burka vagy a nikáb utcai viselésének több európai országban bevezetett tilalmát. A kötet az egyes emberi jogokhoz kapcsolódóan nemcsak az Emberi Jogok Európai Bíróságának releváns esetjogát ismerteti, hanem a Polgári és Politikai Jogok Nemzetközi Egyezségokmánya által létrehozott Emberi Jogi Bizottság döntéseit is. (B. M.)

\section{- Az Európai Unió joga}

Mohay Ágoston-Szalayné Sándor Erzsébet (szerk.)

(Sorozat: Dialóg Campus Szakkönyvek, ISSN 1417-7986; Jogi Szakvizsga Segédkönyvek, ISSN 1587-6659)

Harmadik, átdolgozott kiadás. Dialóg Campus, Budapest-Pécs, 2015

Tankönyv. Terjedelem: 310. Bibliográfia: 302. ISBN 9786155376559 
- A szerzők a pécsi jogi kar oktatói és gyakorló jogászok. A könyv az Európai Unió intézmény- és jogrendszerének tanulmányozásához kíván segítséget nyújtani, elsősorban a jogi szakvizsgára készülők számára. Ennek megfelelően szerkezete a szakvizsga tételsorát követi. A könnyebb felkészülést szolgálja az integrációs szervezet történetével foglalkozó bevezető fejezet, a fejezetek végén található ellenőrző kérdések, valamint az Európai Bíróság releváns ítéleteinek rövid - a tényállást és a ratio decidendit világosan kiemelö - összefoglalásai. A korábbi kiadást annotáltuk a Pro Futuro 2013/1. számában. (Sz. D.)

- EU-jog

Osztovits András (szerk.)

Második, aktualizált és bővített kiadás. HVG-ORAC, Budapest, 2015

Tankönyv. Terjedelem: 605. Bibliográfia a fejezetek végén. ISBN 9789632582788

- A tankönyv szerzői négy jogi kar (KRE, ME, PPKE, SZE) Európa-jogot oktató szakemberei. A kötet célkitüzései között szerepelt az uniós jogot átfogóan bemutató ismeretanyag összefoglalása, az első, 2012-es kiadást követő változások mint például Horvátország uniós csatlakozása vagy az új Európai Bizottság megalakulása -figyelembevételével és feldolgozásával. A tankönyvnek szánt kötet „A" része a klasszikus jog- és intézményrendszert mutatja be, míg a „ $B$ ” rész a belső piac jogáról és az uniós versenyjogról nyújt átfogó ismereteket. Az első kiadást annotáltuk a Pro Futuro 2014/2. számában. (B. F.)

\section{- Nemzetközi légijog: szabályok három dimenzióban}

SIPos Attila

Wolters Kluwer, Budapest, 2015

Kézikönyv. Terjedelem: 363. Bibliográfia: 349-363. ISBN 9789632955292

- A szerző egyetemi oktató. A könyv alapvetően a nemzetközi légijog két legfontosabb alapszerződését: a nemzetközi polgári repülésröl szóló Chicagói Egyezményt (1944) és a nemzetközi légi fuvarozásra vonatkozó egyes jogszabályok egységesítéséröl szóló Montreali Egyezményt (1999) dolgozza fel. Részletesen bemutatja az ENSZ Nemzetközi Polgári Repülési Szervezet (ICAO) müködését, és közel 100 jogesetet is ismertet. A kötet két nagyobb részre tagolódik: elsőként a nemzetközi polgári repülés közjogát, majd a nemzetközi polgári repülés magánjogát tárgyalja, utóbbi keretében a légi közlekedés felelősségi rendszere kapcsán kitérve a magyar jogszabályokra is. (B. M.)

\section{- Az Európai Unió jogi fundamentumai}

Szabó Marcel-Láncos Petra Lea-Gyeney Laura (szerk.)

Ötödik, javított kiadás. Szent István Társulat, Budapest, 2015

Tankönyv. Terjedelem: 334. Bibliográfia a lábjegyzetekben. ISBN 9789632775258

- A szerzők a PPKE JÁK oktatói. A 2012 óta minden évben aktualizált tartalommal megjelenő, joghallgatóknak szánt kötet az uniós jog egészére vonatkozó alapismereteket tartalmazza. Képet nyújt az Unió történetéröl, annak intézményeiröl és müködéséről, és külön részt szentel a belső piac jogának, kitérve a vonatkozó jogesetanyag bemutatására is. Az első kiadást annotáltuk a Pro Futuro 2014/2. számában. (M. B.) 
- Nemzetközi és európai sportjog

SzEMEsı Sándor

Campus Kiadó, Debrecen, 2015

Egyetemi jegyzet. Terjedelem: 118. Bibliográfia: 114-118. ISBN 9789639822573

- A szerző egyetemi oktató. A kötet egy hazánkban még kevéssé feldolgozott témával, a nemzetközi sportjoggal foglalkozik, amely számot tarthat nemcsak a joghallgatók, gyakorló jogászok, hanem akár a sportszövetségi szakemberek érdeklődésére is. A munka a nemzetközi sportjog fogalmi alapvetésein túl foglalkozik az Amerikai Egyesült Államok különböző nemzeti bajnokságaiban alkalmazott szabályozási modellekkel, illetve a dopping elleni fellépés nemzetközi jogi eszközeivel is. Az Európai Unió sportjogára és a Nemzetközi Sport Döntőbíróságra fókuszáló fejezetekben a releváns esetjog, ezen belül számos magyar ügy bemutatására is sor kerül. (B. M.)

\section{JOGBÖLCSELET}

- Közgazdaságtan és jogfilozófia: rendszertelen áttekintés a jog gazdasági elemzésének elméleti és módszertani alapjairól

CSERne Péter

(Sorozat: Recta Ratio, ISSN 2064-7107)

Gondolat, Budapest, 2015

Monográfia. Terjedelem: 384. Bibliográfia a lábjegyzetekben.

ISBN 9789636935368

- A szerző jogász, közgazdász, az angliai hulli egyetem oktatója. A kötet a jog és gazdaság, illetve a jogtudomány és közgazdaságtan viszonyával foglalkozik. Bemutatja a magyar jogtudományban szinte ismeretlen módszertani paradigmát, a racionális döntések elméletét, s tisztázza az ehhez kapcsolódó fogalmakat. A szerző abból a hipotézisből indul ki, hogy a racionális döntések elmélete (RDE) a jogászok számára is jelentős lehet, mind a jogtudományi kutatás, mind a jogi és közpolitikai döntések során hasznos módszertani paradigmát jelenthet. A szerző megadja a jog gazdasági elemzésének (JGE) alkalmazhatóságát, alapfogalmait, módszereit, elmélettörténeti hátterét. Tisztázza annak diszciplináris helyzetét, és segítséget nyújt abban, hogy milyen szerepe lehet a közgazdasági tudásnak a jogpolitikában, jogalkotásban, jogalkalmazásban. Művében felhívja az olvasó figyelmét a JGE korlátaira is, mint amilyenek a jog szabályai és doktrínái mögött meghúzódó előfeltevések, melyekben a hétköznapi emberek erkölcsi elvei, intuíciói húzódnak meg. (G. A.)

- Formalizmus a bírói gyakorlatban: a formalista bírói érvelés jogelméleti alapjai FIcsor Krisztina (Sorozat: Dignitas luris Debreceni Iskola, ISSN 2063-5087; 15.) Gondolat, Budapest, 2015

Monográfia. Terjedelem: 216. Bibliográfia: 201-208. ISBN 9789636936198 
- A szerző a Debreceni Egyetem oktatója, aki - doktori értekezése átdolgozásával készült - könyvében a helyes bírói döntés kritériumait vizsgálja a formalista bírói érvelés szemszögéből, melyet megszabadít a jelenleg is uralkodó kritikus társadalmi nézet negatív felhangjaitól. Abból indul ki, hogy a formalizmus elsősorban normatív elmélet azzal kapcsolatban, hogy a bírónak hogyan kell döntenie; nem köti történelmi korszakhoz a fogalmat, annak egy komplexebb képét tárja az olvasó elé. Nemcsak a bírói gyakorlat problémáira, de a magyar jogelméletben felbukkanó különböző felfogásokra is reagál. A könyv első fejezete meghatározza az ítélkezéselmélet fogalmát, helyét a jogrendszerben, a második magával a bírói formalizmussal foglalkozik. A harmadik megadja a formalizmus jogi értelmezését, majd a negyedik a bírói formalizmus jogelméleti és politikai filozófiai alapjaival foglalkozik. Végezetül a szerző bemutatja a bírói formalizmus elvi határait, különös figyelemmel a „nehéz esetekre”. (G. A.)

- Tanulmányok a jog erkölcsi alapjairól: emberi méltóság, szabad vasárnap, uzsora, pénzügyi világválság

Frivaldszky János (szerk.)

(Sorozat: A Pázmány Péter Katolikus Egyetem Jog- és Államtudományi Karának könyvei, ISSN 2061-7240)

Pázmány Press, Budapest, 2015

Tanulmánykötet. Terjedelem: 191. Bibliográfia a lábjegyzetekben.

ISBN 9789633082454

- A szerző a Pázmány Péter Katolikus Egyetem tanszékvezető egyetemi tanára. Műve négy, az emberi méltóság mint vezérfonal által összekötött tanulmányt foglal magában, melyek témái a következők: az emberi méltóság és a jogképesség, a szabad vasárnap, az uzsora és a kamat, valamint a pénzügyi világválság tapasztalatai. Valamennyi tanulmány átfogó képet ad a feldolgozott témakörről; például az emberi méltóságról, valamint az uzsoráról szóló írások sorra veszik az ókori, középkori gondolkodók, elsősorban Arisztotelész és Aquinói Szent Tamás tételeit, de ugyancsak találhatunk hivatkozásokat a porosz Landrechtre vagy a magyar Ptk.-ra is. Emellett a szerző ismerteti saját álláspontját a témakörök által felvetett, napjainkban is aktuális kérdések, problémák kapcsán: a szabad vasárnap célját például a közös családi programok szervezésében látja, ehelyett azonban az emberek nem tudják tartalmasan eltölteni szabad idejüket. (B. M.)

- A jog tudománya: tudománytörténeti és tudományelméleti írások, gyakorlati tanácsokkal

Jakab András-Menyhárd Attila (szerk.)

HVG-ORAC, Budapest, 2015

Tanulmánykötet. Terjedelem: 925. Bibliográfia a lábjegyzetekben. ISBN 9789632582580

- A tanulmányok szerzői egyetemi oktatók, kutatók. A szerkesztők meghatározása szerint jogtudomány az, amit a magukat jogtudósoknak tekintő egyetemi és akadémiai közösség tagjai jogtudományi kutatásnak tekintve művelnek. A jogtudomány fogalma alá tartozó, különböző célkitűzésủ, társadalmi funkciójú és mód- 
szertani elkötelezettségü tudományágak rendkívüli heterogenitását jól mutatja, hogy a tanulmányok szerzői mintegy kilencszáz oldalt szenteltek a jogtudományi kutatások meghatározásának. A magyar jogtudomány történeti és elméleti bemutatása mellett számos módszertani tárgyú tanulmányt is találhatunk a kötetben. Így különösen jól hasznosítható lehet például a jogi adatbázisokról vagy a jogi szövegek fordításáról szóló írás. A kötet áttekintéséhez részletes tartalomjegyzék és személynévmutató nyújt segítséget. (B. M.)

- Dikologia - Törvényszéki rétorika és jogi érvelés Aristotelésnél

KöNCZÖL Miklós

(Sorozat: Recta Ratio in nuce 2015, ISSN 2064-7107)

Gondolat, Budapest, 2015

Monográfia. Terjedelem: 200. Bibliográfia a lábjegyzetekben.

ISBN 9789636935917

- A szerző jogász, klasszika-filológus. A jogtudományban az egyik legjelentősebb elemzési terület a jogászi érvelés karaktere és müködése. A Dikologia című írás visszanyúl a klasszikus hagyományban megjelenő gondolatokhoz, pontosabban Arisztotelész Rétorika címü művének I. könyvéhez. A szerző lépésről lépésre világítja meg, hogy a törvényszéki érvelés alapjai hogyan jelennek meg Arisztotelész munkájában. Ezzel a vizsgálódással arra is rámutat, hogy a modern jogász is szemezgethet a jogászi érveléssel kapcsolatos arisztotelészi gondolatokból, amelyeket két átfogó fejezetben magyaráz a szerző. Az első fejezetben olvashatunk a retorika alapjairól általánosságban, majd a másodikban a törvényszéki retorikában alkalmazható érvek tulajdonságairól és köréröl. Az utóbbi - amely az elkövetők tudati állapotára vonatkozó érvek körét vizsgálja - érdekes elemzéseket tartalmaz a büntetőjogászok számára, míg a méltányossággal kapcsolatos elemzés megvilágítja, hogy a jogalkalmazó mikor alkalmazhat méltányossági érveket a jogászi érvelés során. ( $F . K$.)

\section{- Decem anni in Europaea Unione I. - Jogtörténeti és jogelméleti tanulmányok} Sáry Pál (szerk.)

(Sorozat: Miskolci Jogtudományi Mühely, ISSN 1589-1518; 6.)

Miskolci Egyetemi Kiadó, Miskolc, 2015

Tanulmánykötet. Terjedelem: 185. Bibliográfia a lábjegyzetekben.

ISBN 9786155216763

- A szerzők egyetemi oktatók. A kötetben 13 különálló tanulmány olvasható, amelyek a Miskolcon 2014. október 1-jén rendezett „Az európai egység eszmei-történeti gyökerei" című konferencián hangzottak el. A konferenciát Magyarországnak az Európai Unióhoz való csatlakozása 10. évfordulója alkalmából szervezték. A kötet meglehetősen sokszínű: magyar nyelvű, elsősorban jogelméleti tanulmányokat tartalmaz, amelyekben olvashatunk arról, hogy vajon milyen hasonlóság mutatható ki a mai uniós és az ókori római kettős polgárság koncepciója között, hogy a történelem során az egyes birodalmak milyen ideológiai alapon tüntették fel magukat egy-egy korábbi birodalom folytatójának, vagy hogy milyen különbségek mutathatók ki az egyes jogi kultúrák között. Ezeken kívül még számos aktuá- 
lis gyakorlati problémákkal foglalkoznak a tanulmányok szerzői. A tanulmányokat a bőséges lábjegyzet és forrásmegjelölés teszi igazán színvonalassá. (Sz. Zsa.)

- Rendszeres jogelmélet

SzABó Miklós

(Sorozat: Prudentia luris 2015, ISSN 1219-8471; 30.)

Bíbor, Miskolc, 2015

Tankönyv. Terjedelem: 269. Bibliográfia: 261-269. ISBN 9786155536090

- A szerző a Miskolci Egyetem Állam- és Jogtudományi Karán egyetemi tanár. E munkája nem pusztán a joghallgatók számára jelent hasznos olvasnivalót, hanem mindazok számára is, akik érdeklődnek a jog elméleti alapjaival kapcsolatos kérdések iránt. „A mi a kémia? vagy mi a gyógyászat? kérdések megválaszolásának nem szenteltek olyan hatalmas irodalmat, mint annak meghatározására, hogy mi a jog" - mondja Herbert Hart. A jogelméletben számos szerteágazó vagy egymásnak ellentmondó válasz született a jog természetével kapcsolatos kérdésekre. Ez a kötet hiánypótló jellegünek tekinthető, mert a jogelméletet foglalkoztató legfontosabb kérdésköröket egy kötetben, rendszerezetten tárgyalja. A szerző a rá jellemző világos és figyelemfelkeltő stílusban tárgyalja végig azokat a problémákat, amelyek a jog természetével és működésével kapcsolatosak. Tizenkét fejezetben öleli fel a jog fogalmának és funkciójának, a jog kötelező erejének igazolási kérdéseit, illetve a jog alkotásával és az ítélkezéssel kapcsolatos elméleti problémákat. (F. K.)

- Problémáink vonzásában: társadalomismereti tanulmányok

SZIGETI Péter

Universitas-Győr, Győr, 2015

Tanulmánykötet. Terjedelem: 328. Bibliográfia a tanulmányok végén.

ISBN 9786155298714

- A szerző egyetemi tanár. Művét több korábbi monográfiájából, tanulmányából szerkesztette össze, és szaktudományok szerint négy fejezetre osztotta. Politológiai, államelméleti, jogelméleti, illetve társadalomelméleti és filozófiai megközelítésből vizsgálta hazánk 2010 és 2015 közötti politikai-társadalmi változásait. Az első részt a politikai tagoltság és jogváltoztatás témájának szentelte, ezen belül vette górcső alá az Alaptörvényt, alkotmányjogi és államelméleti szempontból. A második rész a politikai problémákkal, a nemzetállami szuverenitás közjogi fogalmával foglalkozik, kitérve a rendészeti igazgatás államelméleti alapjaira. A jogelméleti részen belül a jogrend jelentéséről, változásáról és a jogtudományról értekezik. A negyedik rész társadalomelméleti, filozófiai szellemben íródott, ennek fényében fejti ki a kritikai társadalomtudományi megismerés sajátosságait, elmélkedik a materialista lételméletről és Karl Marx gondolatainak jelenkori érvényesülésének lehetőségéről. (G. A.) 
- A rózsa neve: Magyar Köztársaság - Az államok nevéröl és a magyar állam átnevezéséről

TAKÁcs Péter

(Sorozat: Recta Ratio, ISSN 2064-7107)

Gondolat, Budapest, 2015

Monográfia. Terjedelem: 227. Bibliográfia: 125-133. ISBN 9789636935986

- A szerző a Széchenyi István Egyetem egyetemi tanára. Müvének „apropóját” hazánk államnevének 2012. január 1-jével történő megváltoztatása, a Magyar Köztársaság Magyarország elnevezéssel történő felváltása adta. A téma iránt, annak interdiszciplináris volta miatt - az államok elnevezése az államtudomány, a nyelvészet és a földrajztudomány metszéspontján helyezkedik el -, eddig kevesen érdeklődtek, ami a szakirodalom hiányosságában is megmutatkozik, azonban a szerző ennek ellenére átfogóan foglalkozik az államnevek fajtáival, funkcióival, valamint a magyar állam átnevezésének problémájával. A főszöveghez részletes függelék (az államok nevének többféle listája) kapcsolódik. (B. M.)

- Ész, akarat, szabadság - Természetjog és természetes jogok a későskolasztikus gondolkodásban

TATTAY Szilárd

(Sorozat: Recta Ratio, ISSN 2064-7107)

Gondolat, Budapest, 2015

Monográfia. Terjedelem: 258. Bibliográfia a lábjegyzetekben.

ISBN 9789636936006

- A szerző egyetemi oktató, kutató. Meggyőződése, hogy a természetjog és a természetes jogok viszonyának problémája azért van még mindig jelen a jogtudományi vitákban, mert a 13. és 17. század, vagyis az Aquinói Szent Tamás és Hugo Grotius korszaka közötti, átmeneti időszak részletes vizsgálata sosem valósult meg. E kiindulópontból áttekinti a természetjog eszméjének történetét (az ókori természetjogi elméletek kivételével). Könyve három fejezetre osztható, mindben az objektív természetjogot tárgyalja elöbb, és csak azután a természetes alanyi jogokat. Az első és a harmadik fejezet Szent Tamás, illetve Suárez elméletével foglalkozik, míg a második fejezet William Ockham jogfilozófiájával. Vizsgálódásai alapján arra a következtetésre jut a szerző, hogy a természetjog és a természetes jogok között nincs szükségszerü fogalmi ellentét. (G. A.)

- Eszményböl bálvány? A joguralom dogmatikája

VARGA Zs. András

Századvég, Budapest, 2015

Monográfia. Terjedelem: 228. Bibliográfia: 209-227. ISBN 9786155164231

- A szerző egyetemi tanár, a legföbb ügyész helyettese, majd alkotmánybíró. Könyvében részletesen kifejti a jogállam fogalmának alkotmánybírósági értelmezésével és európai uniós felfogásával kapcsolatos aggályait, melyek az önkényesség és a bírói kikényszeríthetőség problémái köré csoportosulnak. Abból a feltevésből indul ki, hogy a jogállamiságnak is lehetséges olyan felfogása - azaz kialakítható olyan hatalomgyakorlás a jogállamiság nevében -, amelyben a jogalanyok egyre 
kevesebb szabadsággal rendelkeznek, és az elvileg a jogaikat, szabadságukat védeni hivatott jog végső soron teljes kiszolgáltatottságukat okozza. Rákérdez arra, hogy a mai jogállamfelfogásunk miért mutat totalitárius jegyeket, miért születnek transzcendens, racionálisan megközelíthetetlen kérdések megválaszolására is jogi megoldások, mintegy bálványozva a joguralmat. A szerző a jog természetes valósága mellett foglal állást. (G. A.)

\section{JOGTÖRTÉNET}

- Tradíció és modernitás a kinai jogrendszerben: a szerződési jog útja a császárkori gyökerektöl a modern szintézisig

BókA János

(Sorozat: A Pólay Elemér Alapítvány Könyvtára, ISSN 1786-352X; 51.)

Pólay Elemér Alapítvány, Szeged, 2015

Monográfia. Terjedelem: 207. Bibliográfia: 183-199. ISBN 9786155411199

- A szerző a Szegedi Tudományegyetem doktorandusza, majd oktatója volt, jelenleg a Nemzeti Közszolgálati Egyetem oktatója. Kötetében, amely PhD-értekezésének átdolgozott változata, korábbi kutatásait összegezve a világ második legnagyobb gazdasággal bíró országának, a Kínai Népköztársaságnak a jogrendszerét mutatja be. Kína jogrendszere nemcsak regionális mintaadó, de a közelmúltban lezajlott polgári jogi kodifikációra tekintettel a jogrendszer ismertetése a hazai jogászság számára is hasznos lehet. A könyv szerkezeti felépítése áttekinthető: elsőként a tradicionális kínai joggal, majd a köztársasági reformokkal ismerteti meg az olvasót, de még mielött levonná következtetéseit, a mü legterjedelmesebb részét - mintegy 100 oldalt - a népköztársasági időszak jogrendszerének szenteli. A felhasznált irodalom példaértékű; a szerző a bőséges angol nyelvű irodalom mellett a vonatkozó nemzetközi szerződéseket, törvényjavaslatokat, jogalkalmazói döntéseket és tekintélyes mennyiségü kínai törvényt ismertet. (D. V.)

- Válogatás a modern magyar honvéd-katonai büntető joghistória forrásaiból, 19451949 l.

Farkas Ádám-Kelemen Roland (szerk.)

Széchenyi István Egyetem Batthyány Lajos Szakkollégium, Győr, 2015

Forrásgyűjtemény. Terjedelem: 197. Bibliográfia: 51-56. ISBN 978963123311 , 9789631233131 (online)

- A kötet szerkesztői a Széchenyi István Egyetem oktatói. A gyüjtemény nem előzmény nélküli, hiszen 2014-ben jelent meg Farkas Ádám szerkesztésében a Válogatás a modern magyar honvéd-katonai büntető joghistória forrásaiból, 18671945 címü munka I. és II. kötete. Jelen kötet célja, hogy megismertesse az olvasót azokkal a jogforrásokkal, amelyek meghatározták az 1945 és 1949 közötti magyar katonai büntetőjogot és igazságszolgáltatást. Munkájával ösztönözni és támogatni kívánja a katonai büntetőjog területén folytatott kutatásokat. Ez a kötet is hiánypótlónak tekinthető abból a szempontból, hogy még a jogásztársadalomnak is csak „gyenge fogalmai” vannak a katonai büntetőjogról. E jogszabálygyűj- 
temény (kiegészülve Kelemen Roland rövid tanulmányával) alapvető forrássá válhat a katonai büntetőjog iránt érdeklődők számára. (D. V.)

- Konföderációs és föderációs elképzelések Közép-Európában (1850-1940): értelmiségi víziók a regionális és közép-európai összefogásról

NÉMETH István

Magánkiadás, Budapest, 2015

Monográfia. Terjedelem: 167. Bibliográfia: 165-167. ISBN 9789631231755

- A kötet szerzője az Eszterházy Károly Főiskola oktatója, a Bölcsészettudományi Kar tanára. Könyve elsősorban a történelem- és politikatudomány módszereit használja, de az Európa-jog müvelői is haszonnal forgathatják. A kötet sorra veszi azokat a 19. és 20. századi politikai irányzatokat, illetve politikusokat, amelyek és akik meghatározó befolyást gyakoroltak vagy kívántak gyakorolni a közép-európai térség alakulására. A felhasznált irodalom mennyisége a könyv terjedelméhez viszonyítva nem igazán bőséges, ugyanakkor növeli a mü értékét, hogy a felhasznált dokumentumok egy része magyarul eddig nem volt hozzáférhető, az a szerző saját fordítása. (D. V.)

- Ünnepi tanulmányok Parádi József 65. születésnapja tiszteletére

Parádi Ákos (szerk.)

(Sorozat: Salutem, ISSN 2416-2078; 2.)

Szemere Bertalan Magyar Rendvédelem-történeti Tudományos Társaság, Budapest, 2015

Tanulmánykötet. Terjedelem: 218. Bibliográfia az egyes fejezetek végén.

ISBN 9789638982896

- Parádi József a magyar rendvédelem-történet kutatásának egyik meghatározó alakja. A könyv az ő köszöntésére, 65. születésnapjának tiszteletére jelent meg. A kötetet laudatio, nyolc tanulmány és az ünnepelt mủveinek válogatott bibliográfiája alkotja. A tanulmánykötetbe neves rendvédelem-történészek publikációi kerültek be, és a kötetet alkotó tanulmányok témáját is a rendvédelemmel kapcsolatos szervek (például a csendőrség), illetve tevékenységek (például a határforgalom ellenőrzése) adják. Így, pl. Boda József tanulmányában az Osztrák-Magyar Monarchia felderítő szerveinek munkáját ismerteti, Lőrincz József pedig az 1956-os forradalom börtönügyi következményeit elemzi. E tanulmányok jogtörténeti szempontból is új eredményeket tartalmaznak. (D. V.)

\section{- Magyar csendörség-történeti tanulmányok}

Parádi József et al. (szerk.)

(Sorozat: Magyar Rendvédelem-történeti Tanulmányok, ISSN 2415-9875; 1.)

Magyar Királyi Csendőr Bajtársi Közösség és Szemere Bertalan Magyar Rendvédelem-történeti Tudományos Társaság, Budapest, 2015

Tanulmánykötet. Terjedelem: 401. Bibliográfia az egyes fejezetek végén.

ISBN 9789638982889

- Jelen kötet tanulmányai elsőként a Rendvédelem-történeti Füzetek (Acta Historiae Praesidii Ordinis) hasábjain jelentek meg. Szerzői a történelemtudomány, az ál- 
lam- és jogtudomány, a hadtudomány és a bölcsészettudomány doktorai, szinte valamennyien egyetemi oktatók, a magyar rendvédelem-történet kutatói. A kötet tizenöt tanulmányt tartalmaz, amelyek ugyanazon téma köré szerveződnek, mégis változatosak. Számos tudományterülettel, így akár a jogtudománnyal foglalkozók számára is újdonságerejüek. A kötetböl kiemelendő Csapó Csaba igazgatástörténeti tanulmánya (A csendörség és a városok 1881-1914) és Zétényi Zsolt munkája, aki a csendőrség és a csendőrök 1945 előtti és azt követő jogállását elemzi és hasonlítja össze. (D. V.)

- Szolnoki jogászok emlékezete - bíróságtörténeti emlékek 1945-től

Pongrácz Zsolt (szerk.)

Szolnoki Törvényszék, Szolnok, 2015

Szakkönyv. Terjedelem: 151. Bibliográfia a lábjegyzetekben.

ISBN 9789631219586

- A szerzők, illetve interjúalanyok gyakorló jogászok, mindannyian a szolnoki igazságszolgáltatási szervekhez köthetőek. A könyv korlenyomat, kordokumentáció, ugyanis az 1945-1989 közötti időszakot mutatja be, nagy hangsúlyt fektetve a személyes beszámolókra. Két nagyobb részből áll; az első részben az előszó keretében egy tanulmány olvasható, amely vázlatos áttekintést ad a megjelölt korszak bírósági történetéröl, a pártállami rendszer sajátosságairól, a korszakra irányadó jogszabályokról és azok gyakorlati jelentőségéröl, valamint a korszak sajátos szervéről, a Koordinációs Bizottságról és annak müködéséről is részletesen beszámol. A második részben tizenegy, elöre feltett kérdések alapján lezajló interjú anyagát tették közzé egységes formában. Ezekben a korszakban tevékenykedő jogászok mesélnek kinevezési körülményeikről, különös esetekről, a rendszer sajátosságairól, így adva korhű képet egy letűnt, sajátos korszak bíróságtörténetéről. (Sz. Zsa.)

- A hazai idegenrendészeti jog vizsgálata a 20. század első évtizedeiben, különös tekintettel a hatósági szervezet bemutatására

SZENTGYÖRGYVÁRI Tamás

Széchenyi István Egyetem Batthyány Lajos Szakkollégiuma, Győr, 2015

Kismonográfia. Terjedelem: 111. Bibliográfia: 105-111. ISBN 978963122517 4, 9789631225181 (online)

- A mủ alapját a szerző diplomamunkája képezi, amelyet további kutatásokkal egészített ki, és amelynek könyv formájában való megjelentetését nem maga a szerző, hanem a kutatást befogadó Batthyány Lajos Szakkollégium vezetése határozta el. A könyv témája, tekintettel a közelmúltban kialakult migrációs válságra, vitathatatlanul aktuális. Szerkezetét tekintve jól tagolt, áttekinthető, az egyes fejezetek címéből is kitünik, hogy jogtörténeti munkával állunk szemben. A könyv jogtörténeti jellegét tovább erősíti az, hogy a szerző nemcsak a témára vonatkozó szakirodalmat dolgozta fel, de országgyülési és levéltári dokumentumokat is felhasznált, $s$ a primer források tükrében, jogtörténeti keretek között értékelte az idegenrendészeti jog 20. századi jelenségeit. (D. V.) 
- Szemelvények Nógrád megye bíróságának történetéböl

Tóth Tamás (szerk.)

Balassagyarmati Törvényszék, Balassagyarmat, 2015

Forráskiadvány. Terjedelem: 350. Bibliográfia nincs. ISBN nincs.

- A könyvet eredetileg a balassagyarmati törvényszéki palota épületének 100 éves évfordulója alkalmából készítették, szerzői gyakorló jogászok és levéltári alkalmazottak. A könyv tulajdonképpen egy bíróságtörténeti forrásgyüjtemény, így elsősorban levéltári forrásokat: adatokat, jegyzőkönyveket, képeket mutat be. Elsődleges célja, hogy a források segítségével bemutassa Nógrád megye sajátosságait a történelem tükrében, hogy hogyan is változtak a bíróságok, és velük együtt maguk a bírák. A könyv alapjául szolgáló kutatás közel 150 év történeti anyagát dolgozza fel, és kiterjed 1871-től kezdve napjainkig, a megyét érintő valamennyi, igazságszolgáltatást befolyásoló eseményre. (Sz. Zsa.)

\section{KÖZIGAZGATÁSI JOG}

- A köznevelési rendszerhez kapcsolódó jogi szabályozás nemzetközi helyzetképe BAJOMI Iván-HaLÁsz Gábor-KovÁcs István Vilmos-PREKOPA Dóra Oktatási Hivatal, Budapest, 2015

Szakkönyv. Terjedelem: 231. Bibliográfia: 221-231. és a lábjegyzetekben. ISBN 9786158001861

- A szerzők egyetemi oktatók, kutatók, a köznevelés területével foglalkozó szakértők. Munkájuk a megújult magyar köznevelési, tanügyi rendszer számára hasznosítható nemzetközi példák, jó gyakorlatok feltárására és beazonosítására irányult. A kötetben több ország, többek között Japán, Anglia, Franciaország közoktatási rendszerének bemutatására kerül sor elöre meghatározott logika mentén. $A z$ „országelemzések”, külföldi helyzetfeltáró tanulmányok külön-külön is megállák helyüket, mivel a bevezetők után a részletszabályok és esetleírások feldolgozását valamennyi alkalommal következtetésekkel és összegzésekkel zárják a szerzők. A szakkönyv megértését jelentősen segítik a fejezetek végén elhelyezett mellékletek és ábrák. A munkát összehasonlító elemzés zárja, amelynek célja a nemzetközi helyzetkép feltárása, a föbb trendek és tendenciák ismertetése. A kötet hasznos olvasmány lehet mindenki számára, aki szélesebb körben érdeklődik a tanügyi kérdések iránt. (B. A.)

- Tüzvédelmi igazgatás

DömÖK Zsuzsanna Katalin-ERDös Antal

Terc, Budapest, 2015

Jegyzet. Terjedelem: 192. Bibliográfia: 192. és a lábjegyzetekben. ISBN 9786155445293

- A szerzők a katasztrófavédelmi igazgatásban dolgozó szakemberek; munkájuk különböző mérnökképzések tananyagához kapcsolódik. A tűzvédelmi igazgatásban a műszaki tudományok mellett a jogi szabályozás is kiemelkedő szereppel rendelkezik. Mindezekre tekintettel a szerzők alapvető törekvése az volt, hogy 
gyakorlatias megközelítéssel foglalkozzanak a szakterület kérdéseivel, ugyanakkor azok jogi kötődését, jogszabályi kontextusát is bemutassák. A kötet foglalkozik a katasztrófavédelmi igazgatás új irányaival, a kapcsolódó közigazgatási jogi ismeretek sajátosságaival, valamint kitér a szakigazgatási terület személyi, szervezeti és eljárási kérdéseinek ismertetésére. Feldolgozza a mérnöki módszereken alapuló Országos Túzvédelmi Szabályzat hatályba lépésével kapcsolatos kérdéseket is. Az áttekintést több helyen táblázatok segítik. (B. A.)

- Gazdaság és közigazgatás - Tanulmányok Ficzere Lajos tiszteletére

Fazekas Marianna (szerk.)

(Sorozat: Bibliotheca luridica. Libri Amicorum, ISSN 1587-1509; 44.)

ELTE Eötvös Kiadó, Budapest, 2015

Tanulmánykötet. Terjedelem: 242. Bibliográfia a lábjegyzetekben.

ISBN 9789633122372

- A szerzők és a szerkesztő egyetemi oktatók. A kötet Ficzere Lajos, az ELTE jogi karának egykori tanszékvezetője tiszteletére készült, akinek közigazgatási jogi munkásságát számos díjjal is elismerték. A tanulmányok öt tematikai egységben szerepelnek, melyek a professzor munkásságát is jellemezték. Az első részben a gazdaság és a közigazgatás viszonyát vizsgáló tanulmányok kaptak helyet, melyek után az Európai Unió és tagállamai közigazgatását bemutató írások szerepelnek. A harmadik részben a kormányzati müködéssel foglalkoznak, míg ezt követően a közigazgatási eljárásjoggal kapcsolatos kérdésekre kaphatunk választ. Az utolsó nagy szerkezeti egységben a felsőoktatás dilemmáival találkozhatunk. A kötet végén Ficzere Lajos tudományos közleményeinek gyűjteménye található. (J. V.)

- Közigazgatás: reform után, átalakítás közben - A 2010-2014-es időszak közigazgatási reformja az érintettek véleménye alapján

GELLÉn Márton

Patrocinium, Budapest, 2015

Szakkönyv. Terjedelem: 144. Bibliográfia a lábjegyzetekben.

ISBN 9789634130666

- A szerző egyetemi oktató, kutatási területe a közszférában való vezetés és motiváció, valamint a közigazgatási reformok. Mint azt a cím is tükrözi, a 2010-2014 között végbement közigazgatási reformokat elsődlegesen a kormánytisztviselők és köztisztviselők véleménye tükrében vizsgálta, a mű végén azonban helyet kapott a lakosság véleménye is. A kutatás a vezetők mélyinterjúi, a kormánytisztviselők által kitöltött online kérdőívek, valamint a lakosság és egyetemi hallgatók által kitöltött kérdőívek segítségével valósult meg. Az empirikus kutatási eredményeit a szerző ábrákkal, táblázatokkal is szemlélteti. (J. V.)

- A hazai és az uniós közigazgatási eljárásjog aktuális kérdései Gerencsér Balázs-Berkes Lilla-Varga Zs. András (szerk.) (Sorozat: A Pázmány Péter Katolikus Egyetem Jog- és Államtudományi Karának Könyvei. Tanulmányok, ISSN 2061-7240; 31.) 
Pázmány Press, Budapest, 2015

Tanulmánykötet. Terjedelem: 574. Bibliográfia a lábjegyzetekben.

ISBN 9789633082461

- A szerzők és a szerkesztők hazai és külföldi kutatók, oktatók és gyakorlati szakemberek. A kötet az Ereky István Közjogi Kutatóközpont 2015. március 5-6-án szervezett konferenciájának eredményeit foglalja össze. A rendezvény a tagállami közigazgatási eljárásjogok vizsgálatát célozta az Európai Unió eljárási modelljének fényében. Ennek megfelelően a tanulmánykötetet tematikai sokszínúség jellemzi. Míg az első részben azok a munkák kaptak helyet, amelyek a magyar és az európai hatósági eljárás szabályozásának aktuális kérdéseit tárgyalják, addig a második részben alapvetően a közigazgatási bíráskodás témáját érintő kutatások eredményeit osztják meg a kutatók. A harmadik nagy szerkezeti egységben az eljárásjogi kodifikáció hazai és EU-s folyamatait ismerheti meg az olvasó, magyar és külföldi kutatók tolmácsolásában. A kötet negyedik részében fiatal kutatók angol nyelvü munkái olvashatók. A kiadvány elektronikusan is elérhető. (B. A.)

- Közszolgálati jog

György István-Hazafi Zoltán (szerk.)

Nemzeti Közszolgálati Egyetem, Budapest, 2015

Tankönyv. Terjedelem: 247. Bibliográfia: 241-244. és a lábjegyzetekben.

ISBN 9786155527159

- A szerzők és a szerkesztők egyetemi oktatók. A tankönyv kifejezetten a közigazgatás személyzeti állományával, a közszolgálati tisztviselőkre vonatkozó jogi szabályozással foglalkozik, ábrákkal, táblázatokkal szemléltetve a tananyagot. Három vetületben tárgyalja a témát, általános része a közszolgálati jog általános kérdéseit elemzi, a Kttv. és Kjt. szabályozási logikáját ismerteti, míg különös része a jogviszony egyes elemeit taglalja részletesen. A harmadik rész a közszolgálati személyzeti igazgatást tekinti át, kitérve a képzés, továbbképzés, adatgyűjtés, érdekegyeztetés, érdekképviselet témaköreire. (V. B.)

- Gondolatok a 21. századi önkormányzati jog fontosabb intézményeiröl és modelljeiről a nyugati demokráciák és Magyarország szabályozásainak, valamint azok változásainak tükrében

HoFfMAN István

(Sorozat: ELTE Jogi Kari Tudomány, ISSN 2060-9361; 30.)

ELTE Eötvös Kiadó, Budapest, 2015

Monográfia. Terjedelem: 297. Bibliográfia: 271-291. és a lábjegyzetekben. ISBN 9789633122310

- A szerző az ELTE ÁJK oktatója, a kötet habilitációs értekezésének könyvváltozata. A munka nem csupán a témakörrel részletesebben foglalkozó kutatók számára szolgál információkkal; a mélyreható történeti és összehasonlító elemzésnek köszönhetően egyetemi hallgatók, gyakorló szakemberek és döntéshozók is haszonnal forgathatják. A szerző alapvető célja annak bemutatása, hogy milyen keretek között fejlődnek a modern önkormányzati rendszerek. Ennek érdekében elsőként az önkormányzatokat érő legújabb kihívásokat és az azokra adott vála- 
szokat, majd a települési és területi autonómiákra vonatkozó alapvetö elméleteket ismerteti. A szerző az áttekintés során külön figyelmet fordít a helyi önkormányzatok alkotmányos jogállásának és szervezetének, pénzügyi alapjainak, valamint a többi állami szervvel fennálló kapcsolatrendszerének bemutatására. (B. A.)

- Az önkormányzat jogállása és döntési kompetenciája

KónYA László-FARKAS Zsolt-Pusztal Adél-TózsA István-Simon Barbara-TótH Ferenc Nemzeti Közszolgálati Egyetem, Budapest, 2015 Oktatási segédanyag. Terjedelem: 132. Bibliográfia az egyes fejezetek végén. ISBN 9786155057380

- A szerzők gyakorló szakemberek és egyetemi oktatók. Céljuk, hogy a jogszabályi változásokat követve átfogó képet adjanak a helyi önkormányzatokról, elsősorban az önkormányzati szakértő szakirányú továbbképzési szak hallgatói számára. A kötet bemutatja az önkormányzatok államon belüli szerepét, valamint kapcsolatát a többi állami szereplővel, nagy hangsúlyt fektetve az önkormányzati döntésekre, valamint a közfeladatokra. A mű szerkezete logikus, jól követhetö, a kulcsszavak, felsorolások kiemelése megkönnyíti az áttekintést. Az egyes fejezetek végén önellenőrző kérdéseket is találunk. (J. V.)

- Fejezetek a magyar e-közigazgatás történetéböl (1998-2010) Molnár Szilárd-Sikolya Zsolt (szerk.)

Primaware, Szeged, 2015

Tanulmánykötet. Terjedelem: 219. Bibliográfia a lábjegyzetekben. ISBN 9789633064177

- A kötet szerzői egyetemi oktatók és a szabályozásban részt vevő szakemberek. A tanulmánykötet célkitüzése, hogy átfogóan mutassa be az elektronikus közigazgatás hazai szabályozási hátterét, kialakulását, fejlődési fázisait, valamint szervezetét, alapvetően az 1998 és 2010 közötti időszakra koncentrálva. Az elöbbiek érdekében bepillantást nyerhetünk a kormányzati politikába, a stratégiaalkotás folyamatába, miértjébe, továbbá olvashatunk az uniós pályázatok gyakorlati megvalósulásáról, és a helyi önkormányzati informatikai helyzetről. (V. B.)

- Magyary Zoltán összes munkái (1888-1945)

Patyi András (szerk.)

Nemzeti Közszolgálati Egyetem, Budapest, 2015

Tanulmánykötet. Terjedelem: 237. Bibliográfia a jegyzetekben.

ISBN 9786155527142

- Magyary Zoltán halálának 70. évfordulójára készült ez a tanulmánykötet, amely egy, a professzor életmüvét középpontba állító könyvsorozat kezdő kötete. A könyvsorozat célja, hogy Magyary Zoltán 1919 és 1922 között megjelent munkáit egy sorozatban újra elérhetóvé tegye, emellett kritikai kiadásként bemutassa az egyes művek hátterét, és az életmü egyes darabjai közötti összefüggéseket. Személy-, szervezetinév-, tárgy-, jogszabály- és címmutatóval segíti az áttekinthetőséget. Foglalkozik az egyes szakpolitikai kérdések bemutatásával, a közigazgatási reformmal és az akkori államtudományi oktatás helyzetével. (V. B.) 
- Európai közigazgatás

Torma András (szerk.)

Miskolci Egyetemi Kiadó, Miskolc, 2015

Tankönyv. Terjedelem: 257. Bibliográfia: 251-257. ISBN 9786155216350

- A 2012-es kiadás változatlan utánnyomása. Annotációját lásd a Pro Futuro 2014/2. számában. (J. V.)

- Az információs társadalom kihívásai és a közigazgatás reakciói

VeszPrémı Bernadett

Debreceni Egyetemi Kiadó, Debrecen, 2015

Egyetemi jegyzet. Terjedelem: 210. Bibliográfia: 209-210. és a jegyzetekben.

ISBN 9789633184844

- A szerző egyetemi oktató. A jegyzet elsősorban egyetemi tananyagként szolgál: felépítése is a tananyag elsajátításának elősegítésére törekszik, a fejezetek végén pedig ehhez önellenőrző kérdések találhatók. A munkának azonban a közigazgatás dolgozói is hasznát vehetik, hiszen rávilágít a gyakorlat legfontosabb problémáira is. A hallgatók vizsgára való felkészülését könnyítendő az egyes fejezetek elején egybegyűjtve találhatóak meg az adott részhez szükséges alapfogalmak. A tananyag elsajátítását ábrák, táblázatok segítik. (J. V.)

\section{MUNKAJOG}

- Külföldiek magyarországi foglalkoztatása

Ács Vera Judit

Wolters Kluwer, Budapest, 2015

Kézikönyv. Terjedelem: 211. Bibliográfia a lábjegyzetekben.

ISBN 9789632954660

- A szerző a Nemzeti Rehabilitációs és Szociális Hivatal munkatársa. Kézikönyve gyakorlati segítséget nyújt a külföldi személyek foglalkoztatásához, mind a munkáltatói, mind a munkavállalói oldal számára. Külön foglalkozik a szabad munkavállalás jogával rendelkező uniós polgárok, valamint a harmadik országból érkezett olyan külföldi munkavállalók foglalkoztatására vonatkozó rendelkezésekkel, akiknek a munkavállalás megkezdéséhez több adminisztratív kötelezettséget kell teljesíteni. A feldolgozás teljes körü, a vonatkozó jogszabályok lényegének ismertetésével a szerző bemutatja a beutazási és tartózkodási feltételeket, a lehetséges foglalkoztatási formákat, a foglalkoztatás feltételeit, az eljárási szabályokat, hatóságokat és költségeket, azzal a céllal, hogy a külföldi foglalkoztatással kapcsolatban felmerülő valamennyi kérdésre választ adjon. (P. Á.)

- Top 100 munkajogi kérdés és válasz

ANTALÓczy Emese-BodnÁR Lilla-Fodor T. Gábor-Füsthy Zsolt-GYÖRI Éva-HARGITTAY Szabolcs-JónÁs Tünde-KÁRTYÁs Gábor-KovÁcs Szabolcs-MÁnYAi Nóra-Marencsák Zsolt-RÁcz Réka-Szücs Péter

Harmadik, átdolgozott kiadás. Wolters Kluwer, Budapest, 2015

Kézikönyv. Terjedelem: 149. Bibliográfia nincs. ISBN 9789632950372 
- A szerzők a munkajog területén tevékenykedő gyakorló jogászok, akik a munka világában nagy relevanciával bíró kérdések megválaszolását tűzték ki célul, a 2012. évi I. törvény hatálybalépése óta ugyanis mind munkáltatói, mind munkavállalói oldalon számos gyakorlati kérdés merül fel. A szerzők a kötet összeállítása során arra törekedtek, hogy olyan kérdéseket válasszanak ki, amelyeket nagy fokú bizonytalanság övez. Ennek megfelelöen többek között a munkaidő, a munka dijjazása, a munkaviszony létesítése és megszüntetése, illetve a felelősségtan kérdései (visszakövetelhető-e a túlvett szabadságra járó díjazás, van-e elvárt bér behívásos munkaviszony esetén, ha a munkáltató az adott hónapban nem tud behívást foganatosítani) kerülnek megválaszolásra a kötetben. (Sz. A.)

\section{- Atipikus munkajogviszonyok}

BANKó Zoltán-FERENCZ Jácint

Wolters Kluwer, Budapest, 2015

Kézikönyv. Terjedelem: 216. Bibliográfia a lábjegyzetekben. ISBN 9789632954585

- A szerzők egyetemi oktatók, az atipikus munkaviszonyok kutatói. A kézikönyv rövid áttekintést nyújt az atipikus munkaviszonyok magyar szabályozásáról, illetve bemutatja az Európai Unió azon jogalkotási aktusait is, amelyek a kérdéskört szabályozzák. Az atipikus jogviszonyok feldolgozását a szerzők nem csupán a Munka Törvénykönyve alapján végezték el, hanem arra törekedtek, hogy a magyar jogrendben szabályozott olyan megoldásokat vegyenek számba és mutassanak be, amelyek a foglalkoztatás hagyományostól eltérő formái közé sorolhatóak. (P. Á.)

\section{- Atipikus foglalkoztatási formák}

FERENCZ Jácint

Dialóg Campus, Budapest-Pécs, 2015

Monográfia. Terjedelem: 179. Bibliográfia: 172-179. ISBN 9789637296970

- A szerző egyetemi oktató és gyakorló jogász, monográfiájának alapját a témában született PhD-dolgozata adja. A mü a munkajog dinamikusan fejlődő területéröl, az atipikus munkaviszonyokról ad pillanatképet, komplex - szociológiai, közgazdaságtani, közpolitikai és jogtudományi - megközelítésben. A könyv a Munka Törvénykönyvében nevesített és nem nevesített, a hagyományostól eltérő foglalkoztatási formákat elemzi, miközben arra a kérdésre keres és ad választ, hogy milyen formában és milyen módon müködik Magyarországon az atipikus foglalkoztatás. (P. Á.)

- Munka és család a munkajog tükrében

Göndör Éva

Universitas-Győr, Győr, 2015

Monográfia. Terjedelem: 305. Bibliográfia: 294-305. és a lábjegyzetekben. ISBN 9786155298608

- A szerző egyetemi oktató, gyakorló jogász. Kötetében a gyermekvállalással és anyasággal kapcsolatos munkajogi és szociális jogi rendelkezések bemutatására vállalkozik. A mű hat fejezetből áll. Az első három (az 1840-es évektől kezdődően) 
a magyar szabályozás kialakulását és annak hatályos rendelkezéseit vizsgálja, különös tekintettel az anyasági ellátásokra és gyermeket nevelökre vonatkozó speciális munkajogi szabályokra. A 4-6. fejezet a téma nemzetközi hátterét hivatott megismertetni az olvasókkal, többek között az Európai Szociális Charta, valamint az Európai Unió és az ILO égisze alatt elfogadott nemzetközi egyezmények bemutatásán keresztül. (Sz. A.)

\section{- Munkajogi kárfelelősség a gyakorlatban}

HanYu Henrietta

(Sorozat: Munkajogi Kiskönyvtár, ISSN 2063-6393; 7.)

Wolters Kluwer, Budapest, 2015

Kézikönyv. Terjedelem: 242. Bibliográfia a lábjegyzetekben.

ISBN 9789632954646

- A szerző gyakorló jogász. A mű a munkajogi kárfelelősség szabályait dolgozza fel átfogóan, jogesetek magyarázatán keresztül, a gyakorlat szemszögéböl. A 2012. évi. I törvény - a jelenleg hatályos Munka Törvénykönyve - számos kérdésben hozott alapvető változásokat a munka világában. Az egyik ilyen terület a kárfelelősség, mely a munkáltató esetében kedvezőbb, míg a munkavállalók oldalán szigorúbb szabályozást jelent. Mindemellett teljesen új elemként került bevezetésre a kártérítés méltányossági alapon történő csökkentésének lehetősége, amelyet szintén tárgyal a kötet. A mü külön fejezetben foglalkozik a munkavállaló, valamint a munkáltató kárfelelősségével, a munkavállalói biztosíték jogintézményével, továbbá az atipikus munkaviszonyban érvényesülö kárfelelősség kérdéseivel. (Sz. A.)

\section{- Bevezetés a közszolgálati munkajogba}

Kártyás Gábor (szerk.)

ELTE Eötvös Kiadó, Budapest, 2015

Jegyzet. Terjedelem: 177. Bibliográfia nincs. ISBN 9789633122228

- A szerzők egyetemi oktatók. Egyetemi jegyzetük szemléletesen mutatja be a közszolgálati munkajog sajátosságait, alapelveit, alanyait, a jogviszony tartalmára, felelösségi rendszerre vonatkozó szabályokat, követve a közszolgálati tisztviselőkről szóló 2011. évi CXCIX. törvény felépítését. A vonatkozó jogszabályok ismertetése jól strukturált, könnyen érthető formában történik, táblázatokkal, ábrákkal szemléltetve egyes rendelkezések lényegét, azzal a céllal, hogy segítséget nyújtson a közszolgálati munkajog szabályainak az elsajátításához. A részletszabályok bemutatása helyett a szerzők a legfontosabb intézmények megértetésére helyezik a hangsúlyt. (P. Á.)

- Kommentár a foglalkoztatási törvényhez: kommentár a foglalkoztatás elösegítéséröl és a munkanélküliek ellátásáról szóló 1991. évi IV. törvényhez

Kovács Szabolcs-TAKÁcs Gábor

Wolters Kluwer, Budapest, 2015

Kommentár. Terjedelem: 260. Bibliográfia nincs. ISBN 9789632955278 
- A szerzők gyakorló jogászok. A kiadvány a foglalkoztatás elősegítéséről és a munkanélküliek ellátásáról szóló 1991. évi IV. törvény 2015. július 1-jén hatályos szakaszainak magyarázatát tartalmazza. A jogszabályhoz füzött magyarázatba épül, vagy felsorolásszerüen azt követi a rendelkezés megértését szolgáló, kapcsolódó joganyag ismertetése, mind a hazai, mind az uniós szabályokra kiterjedően. A jogszabályok leírásán és értelmezésén túl a szerzők - egy kommentártól várható terjedelemben és részletezettséggel - bemutatják a vonatkozó uniós és hazai joggyakorlatot is. (P. Á.)

- Európai és magyar összehasonlitó kollektív munkajog

Prugberger Tamás-NÁdAs György

Wolters Kluwer, Budapest, 2015

Szakkönyv. Terjedelem: 255. Bibliográfia az egyes fejezetek végén.

ISBN 9789632955070

- A szerzők egyetemi oktatók. A tankönyvként is funkcionáló kötet a kollektív munkajog rendszerét mutatja be az európai és magyar szabályozás alapján. Sorra veszi a kollektív munkajog intézményrendszerét, összegzést ad azok történetéről és hatályos szabályozásáról, különválasztva a nyugat-európai, a kelet-közép-európai és a magyar szabályozás jellemzőit. A munka, amely a kollektív munkajog elemeit egymás viszonyrendszerében értékeli, egyes esetekben összegző értékelést ad a magyar kodifikáció számára. (P. Á.)

- A munkáltatói kárfelelősség alakulása a bírói gyakorlat tükrében

SIPKA Péter

HVG-ORAC, Budapest, 2015

Monográfia. Terjedelem: 237. Bibliográfia: 213-237. és a lábjegyzetekben. ISBN 9789632582917

- A szerző egyetemi oktató és gyakorló jogász. Könyvében a munkajogi felelösség szabályainak alakulása kerül bemutatásra, amely különös aktualitást kapott azáltal, hogy a 2012-es Munka Törvénykönyve megváltoztatta a munkáltató felelősségére vonatkozó szabályokat, és a korábbitól eltérő, polgári jogias szemlélet alapján rendezte azokat újra. A szerző a munkáltatói felelősség ezen szemlélet által meghatározott, komplex elemzését végzi el, látóterébe vonva a munkavédelem és a társadalombiztosítás felelősségi szabályait is. A mű a hazai szabályok bemutatásán túl a bírói joggyakorlatot és a téma nemzetközi hátterét is megvilágítja. (Sz. A.)

\section{PÉNZÜGYI JOG}

- Pénzügyi szolgáltatások fogyasztói szemszögböl

Bódy László-FeHÉRVÁRI Erzsébet-HaLÁsz Balázs-Katona Klára

(Sorozat: Közgazdaságtan Joghallgatók Számára, Pázmány Péter Katolikus Egyetem Jog- és Államtudományi Kar Heller Farkas Közgazdaságtudományi Intézet, 1416-695X) 
Negyedik, átdolgozott kiadás. Szent István Társulat, Budapest, 2015

Egyetemi jegyzet. Terjedelem: 130. Bibliográfia nincs. ISBN 9789631665468

- A szerzők egyetemi oktatók. Oktatási segédanyaguk célja, hogy segítséget nyújtson a közgazdaságtant tanuló joghallgatók számára a pénzügyi szolgáltatásokkal kapcsolatos ismeretek elmélyítésében. A mü a pénzügyi szolgáltatásokkal foglalkozik, kiemelt figyelmet fordítva a hitelezés jellemzőire, kockázataira, az ezzel összefüggő fogyasztóvédelmi kérdésekre, valamint a lakossági hitelezésre. A bankokat mint veszélyes üzemeket mutatja be, mivel azok nem saját, hanem ügyfeleik pénzével gazdálkodnak; továbbá ismerteti a pénzgazdálkodás kereteit adó (törvényben szabályozott) felügyeleti szerveket is. A kiadvány végén, mintegy szemléltetésként, táblázatos összefoglalók kapnak helyet, valamint a gyakorlatban használatos formanyomtatványok, szerződések. (L. D.)

- Magyar pénz- és tökepiaci rendszer

Botos Katalin-Bódı László

Szent István Társulat, Budapest, 2015

Egyetemi jegyzet. Terjedelem: 151. Bibliográfia a fejezetek végén.

ISBN 9789632771809

- A szerzők egyetemi oktatók és gyakorlati szakemberek. A kiadvány a magyar pénz- és tőkepiaci rendszer tematikus áttekintése céljával íródott. Szerkezetét tekintve nyolc egységre tagolódik. A szerzők elsőnek a bankrendszer kialakulását általános jelleggel, és a hazai bankrendszer történetét, majd a bankrendszer első és második szintjének müködését, feladatait és intézményeit mutatják be. A negyedik rész a bankok által viselt kockázatokat járja körül, míg az ötödik a hitelintézetek biztonságos müködését garantáló szabályok ismertetését tüzi célul. Ezt követően az olvasók az egyes bankmüveleteket ismerhetik meg, továbbá a biztosítási piac és az értékpapírpiac müködésébe nyerhetnek betekintést. A kiadvány hasznos ismereteket nyújt az egyetemi képzés keretében zajló pénzügyi jogi tárgyú stúdiumok hallgatói számára. (V. J.)

- Uniós pénzügyek - Az európai integráció fejlődésének pénzügyi jogi vizsgálata CsÜRÖs Gabriella HVG-ORAC, Budapest, 2015 Monográfia. Terjedelem: 413. Bibliográfia: 373-414. ISBN 9789632582733

- A szerző egyetemi adjunktus, e munkája a 2012-ben megvédett doktori értekezésének átdolgozása. A nemzetközi pénzügyi jog, a gazdasági integrációk és a pénzügyi föderalizmus elméleti közegébe helyezve vizsgálja az Európai Uniót. A gazdasági integráció különböző formáit az EU belső és külső viszonyrendszerében egyaránt bemutatja, kiemelve azok pénzügyi jogi sajátosságait. A vizsgálat tárgyát a gazdaságpolitikai együttmüködés szabályozásának története, illetve a szabályozásnak a válság által generált változásai képezik, így az új, többpilléres felügyeleti rendszer, az euróövezeti tagállamok költségvetési felügyeletének további erősítését célzó intézkedések, valamint a bankunió. Az EU támogatáspolitikája témakörében a vissza nem térítendő támogatások feltételrendszerének a gazdasági kormányzással való összefonódását, valamint a válság által módosí- 
tott hitelmechanizmusokat elemzi a szerző. Az átláthatóságot, megértést segítik az ábrák és táblázatok. (V. J.)

- A kockázati tökebefektetések egyes jogi kérdései

GLAVANITS Judit

Universitas-Györ, Györ, 2015

Monográfia. Terjedelem: 319. Bibliográfia: 154-167. ISBN 9786155298738

- A szerző a Széchenyi István Egyetem oktatója, e munkája a 2012-ben megvédett doktori értekezésének bővített változata. A kötet a kockázati tőkebefektetések jogi és gazdasági környezetének bemutatását célozza, elsősorban magyar, másodsorban pedig nemzetközi viszonylatban. Magyarországon a kockázati tőkebefektetések mintegy két évtizedes múltra tekintenek vissza, azonban a piac új lendületet vett az utóbbi években, így a szabályozásnak, illetve magának a jelenségnek az értelmezése is kihívást jelent a jogtudomány számára. Ehhez kíván átfogó képet adni a szerző e különleges ügylettípus szabályozásának történeti áttekintésével és az egyes magánjogi vonatkozásainak a feltárásával, valamint a kötet kiváló mellékleteivel. (H. B.)

- Pénzügyi jog I-II.

Halustyik Anna (szerk.)

(Sorozat: A Pázmány Péter Katolikus Egyetem Jog- és Államtudományi Karának Tankönyvei, ISSN 2062-0837)

Pázmány Press, Budapest, 2015

Tankönyv. Terjedelem: 469 (I. kötet), 272 (II. kötet). Bibliográfia a lábjegyzetekben. ISBN 9789633080979 (I. kötet), 9789633080955 (Il. kötet)

- A 2013-as kiadás változatlan utánnyomása. Annotációját lásd a Pro Futuro 2015/1. számában. (B. P.)

\section{- Önkormányzati gazdálkodás}

HolCZREITER Marianna-PAPp Emese-Simon Barbara

Nemzeti Közszolgálati Egyetem, Budapest, 2015

Egyetemi jegyzet. Terjedelem: 125. Bibliográfia a fejezetek végén.

ISBN 9786155057397

- A szerzők gyakorlati szakemberek, egyetemi oktatók. A jogszabályok ismertetésén alapuló jegyzetük a helyi önkormányzatok gazdálkodásának kérdéseit tárgyalja, tizenegy fejezetben. Az államháztartás általános jellemzését követően a költségvetési tervezés központi szintű feladatainak számbavételére kerül sor, majd kifejezetten a helyi önkormányzati alrendszer költségvetési, illetve vagyongazdálkodási szabályainak bemutatására vállalkoznak a szerzők. Külön elemzés tárgyát képezi az államháztartási számvitel rendszerének megváltozása, az önkormányzati humáneröforrás-gazdálkodás, valamint az adósságkonszolidáció és adósságrendezés. Végezetül egyes helyi közszolgáltatások finanszírozásának bemutatására és a gazdálkodás ellenörzésére vonatkozó szabályok kerülnek ismertetésre. Mivel az egyes fejezetek tárgykörei az egyes közpénzügyi témák szerint váltakoznak, a leírtakban kevéssé érvényesül a koherencia. (B. P.) 
- Magasfeszültség - Városi szolgáltatások

HoRváth M. Tamás

(Sorozat: Közszektor-olvasmányok, ISSN 1417-7986)

Dialóg Campus, Budapest-Pécs, 2015

Monográfia. Terjedelem: 278. Bibliográfia: 255-267. ISBN 9786155376603

- A szerző egyetemi tanár, a pénzügyi jog és a közszolgáltatás-szervezés tudományának elismert hazai képviselője. A monografikus kötet a városi közszolgáltatások körében és szervezésében bekövetkező nemzetközi és hazai változásokat teszi kritikai vizsgálat tárgyává. Hat tematikus fejezet keretében tizenhat tanulmány járja körül a témát. Az első két rész a helyi kormányzás, a méret és demokrácia, illetve a térszervezés és hatékonyság kérdéseit elemzi. Míg a harmadik rész az önkormányzatai rendszer finanszírozási és vagyongazdálkodási helyzetét, addig a negyedik már a városi kormányzás keretében ellátott egyes feladatok körét, ellátási módozatait vizsgálja, különösen a közmüszektorban. Az ötödik és a hatodik rész a nemzetközi színtéren bekövetkező változásokat veti össze a hazai folyamatokkal, miáltal a városi szerepek átalakulásáról kaphat képet az olvasó. A változások megértését számos hazai és külföldi gyakorlati példán keresztül, esettanulmány bemutatásával, továbbá ábrákkal és táblázatokkal segíti a szerző. (B. P.)

- Természetes személyek és vállalkozások költségvetési kapcsolatai KÁrolyı Géza-Törő Emese

Kebo Print, Debrecen, 2015

Egyetemi jegyzet. Terjedelem: 178. Bibliográfia: 178. ISBN 9789631239522

- A szerzők közgazdász-jogász egyetemi oktatók és gyakorlati szakemberek. A kiadvány a magánszemélyek és a vállalkozások közjog által szabályozott, költségvetéssel összefüggő jogviszonyaira fókuszál, előbbi jogalanyok közterheinek - adók, járulékok, hozzájárulások, díjak, valamint illetékek - áttekinthető, komplex bemutatására vállalkozik. A kötet hét részre tagolt. Az első egység az adózás rendjét jellemzi, valamint meghatározza az adózással összefüggő alapfogalmakat. A második és harmadik rész a természetes személyeket általában, illetve vállalkozási tevékenység folytatása esetén sújtó közterheket tekintik át. A negyedik szerkezeti egység a társas vállalkozások eredménye után fizetendő adókkal foglalkozik, a következő pedig munkáltatói aspektusból a foglalkoztatással összefüggő fizetési kötelezettségeket rendszerezi. Külön részben kapott helyet a vagyont és a fogyasztást terhelő adók bemutatása. ( $V$. J.)

- Fogyasztóvédelem a pénzügyi szektorban Magyarországon és az Európai Unióban - avagy az acquis communautaire érvényesülése a magyar hitelpiacon Kovács István-SZÁnTHó Miklós-TöRcsı Péter Alapjogokért Központ-Jogállam és Igazság, Budapest, 2015 Tanulmánykötet. Terjedelem: 209. Bibliográfia: 205-209. ISBN 9789631240870

- A szerzők az Alapjogokért Központ alapítói, szakértői. A kiadvány a központ tematikus blogjának pénzügyi fogyasztóvédelemmel kapcsolatos, új tartalmakkal bővített írásait foglalja egységes kötetbe. Az uniós hitelpiacon érvényesülö, fogyasz- 
tóvédelemmel kapcsolatos, legfontosabb rendelkezéseket veti össze a magyar szabályozással. Bemutatja azt az uniós intézményi és hatásköri rendszert, mely a pénzügyi fogyasztóvédelmi szabályok és a jogalkalmazás alakításáért felelős. A hazai jogszabályokat uniós szemszögböl tanulmányozza. A szerzők a jövőre nézve előzetes felvetéseket és építő jellegü kritikákat is megfogalmaztak írásaikban. (Sz. K.)

\section{- A devizahitelezés nagy kézikönyve}

Lentner Csaba (szerk.)

Nemzeti Közszolgálati és Tankönyvkiadó, Budapest, 2015

Kézikönyv. Terjedelem: 613. Bibliográfia a fejezetek végén. ISBN 9786155344626

- A szerzők gyakorlati szakemberek és oktatók, kutatók. A terjedelmes kötet megjelenését és a mögöttes kutatások elvégzését a devizahitelezés társadalmi problémává válása indokolta. Áttekintést kíván adni a mü a devizahitelezés problematikájának keletkezéséröl, lényegéről, kezelési módjairól. Részletesen bemutatásra kerülnek a lakossági és az önkormányzati szektor túlméretezett devizahitelezésének okai és következményei, továbbá a 2011-töl meginduló konszolidációs folyamatok. Az olvasó nemcsak a pénzügyi kutatásban és bírósági ítélkezésben jártas szakemberek tanulmányaival ismerkedhet meg, hanem fiatal kutatók empirikus vizsgálataival is. (H. B.)

- Költségvetési szervek gazdálkodása és pénzügyei

Szamkó Józsefné

Második kiadás. Wolters Kluwer, Budapest, 2015

Kézikönyv. Terjedelem: 287. Bibliográfia: 287. ISBN 9789632954707

- A szerző a közpénzügyek, különösen a költségvetési gazdálkodás és az államháztartási számvitel elismert szakértője. A kézikönyv a 2013. évi kiadvány átdolgozott kiadása, amely a 2014. évi, valamint 2015. év eleji jogszabályváltozásokra, valamint kisebb szerzői hangsúlyeltolódásokra tekintettel, az eredetivel megegyező struktúrában mutatja be a költségvetési szervek gazdálkodására vonatkozó szabályokat. Ezek alapján az átdolgozott kiadásban módosult a maradványelszámolásról és a beszámolókészítési, adatszolgáltatási kötelezettségekről szóló fejezet, kiegészült a kézikönyv az állami tulajdonú gazdasági társaságok átalakítására vonatkozó rendelkezésekkel, az általános forgalmi adózás szabályait leíró rész pedig rövidült. A korábbi kiadás annotációját lásd a Pro Futuro 2015/1. számában. (Sz. K.)

- Az adótörvények változásai I-II.

SzÁRAZ Tünde-ANDRÁsI Jánosné-SzÉLL Zoltánné

(Sorozat: Adózási Kézikönyvek, ISSN 1788-0165; Saldo Szakkönyv, ISSN 15865975)

Saldo, Budapest, 2015

Kézikönyv. Terjedelem: 71 (I. kötet), 112 (II. kötet). Bibliográfia nincs. ISBN nincs.

- A szerzők elismert adószakértők, akik a kétkötetes müben az adótörvények 2015-ös változásaival foglalkoznak. A könyv nemcsak jogszabályokat, hanem gyakorlati, 
problémaorientált kérdéseket is elemez egyes fizetési kötelezettségek vonatkozásában, így ajánlott a szakemberek, illetve a téma iránt általában érdeklődők számára is. A mü a legelterjedtebb közterhekkel foglalkozik, így az általános forgalmi adóval, a személyi jövedelemadóval, a társadalombiztosítási járulékokkal, a társasági adóval, a kisadózó vállalkozások tételes adójával, valamint az utóbbi kettővel összefüggésben a kisvállalati adóval. A jogforrási háttér pontos jelölésével segíti az olvasó eligazodását a jogszabályváltozások útvesztőiben, ami a gyakran változó adójogi normák kapcsán különösen hasznos. (L. D.)

- Az Áfa jogalkalmazást elősegítő Európai Bírósági döntések VARGa Norbert-Vincze Péter-VIRA Sándor

Saldo, Budapest, 2015

Kézikönyv. Terjedelem: 337. Bibliográfia a lábjegyzetekben. ISBN 9789636384852

- A szerzők okleveles adószakértők, adótanácsadók. Az Adózási kézikönyvek sorozatban megjelent kiadványba az Európai Bíróság azon ítéletei kerültek bele, amelyek az általános forgalmi adó hazai joggyakorlatára jelentős hatással voltak és vannak. Jelen kötet különbözö jogeseteket sorakoztat fel tematikusan, majd ezeket feldolgozza. Minden egyes ismertetett ügynél a szerzők egy rövid, de egzakt tényállást fogalmaznak meg, röviden összefoglalják, majd részletesen bemutatják a bírósági döntést, így segítve az egyes ítéletek értelmezését. A mű a forgalmiadó-szakértő képesítés megszerzéséhez szükséges olyan alapvető bírósági döntéseket mutat be, mint a Salix-ügyben, a Deutsche Bank-ügyben vagy az Ecotrade-ügyben született határozatok. A kötet nemcsak a képzés követelményeinek a teljesítéséhez nyújt segítséget, hanem az adózással foglalkozó szakembereknek is, az adóellenőrzések megállapításaival szembeni jogorvoslatok során, a megfelelő érvek, ellenérvek megfogalmazásában. (H. B.)

- Pénzügy(rendszer)tan

VIgVÁRI András

Akadémiai Kiadó, Budapest, 2015

Tankönyv. Terjedelem: 469. Bibliográfia a fejezetek végén. ISBN 9789630585958

- A 2014-es kiadás változatlan utánnyomása. Annotációját lásd a Pro Futuro 2016/1. számában. (B. P.)

\section{POLGÁRI JOG ÉS POLGÁRI ELJÁRÁSJOG}

\section{- Grundrechte im Zivilprozess}

Ahrens, Martin- Lipp, Volker-Varga István (szerk.)

(Sorozat: ELTE Jogi Kari Tudomány, ISSN 2060-9361; 32.)

ELTE Eötvös Kiadó, Budapest, 2015

Tanulmánykötet. Terjedelem: 317. Bibliográfia a lábjegyzetekben.

ISBN 9789633121696 
- Az ELTE ÁJK és a göttingeni Georg August Egyetem közös szemináriumsorozatában az egyetemek polgári jogi, polgári eljárásjogi tanszékei a polgári eljárásjog egy-egy kiválasztott témaköréröl referátumok és tudományos tanácskozások keretében értekeznek. Jelen kötet a harmadik alkalommal megrendezett szeminárium előadásainak írásos anyagát foglalja össze. A szeminárium központi témája az alapjogok érvényesülése a polgári perben, különös tekintettel a tárgyalás alapelveire, a kétoldalú meghallgatás elvére, a tisztességes eljáráshoz való jogra. Utóbbi tekintetében kifejezetten az eljárás időtartamára, a fegyveregyenlőség és a nyilvánosság elvére, a jogorvoslathoz való jogra koncentráltak a résztvevők. A magyar Pp. és a német ZPO alapelveinek összehasonlító elemzése is megjelenik a tanulmányokban, aminek különös aktualitást adott a magyar polgári perrendtartás kodifikációja. A tizenegy német és hat magyar szerző írását - egy angol nyelvű tanulmány kivételével - német nyelven tartalmazza a kötet. (F. Á.)

\section{- Lehetetlen szerződések: jog-összehasonlító metszetek}

BÁn Dániel

HVG-ORAC, Budapest, 2015

Monográfia. Terjedelem: 313. Bibliográfia: 299-313. ISBN 9789632582665

- A szerző a Budapesti Corvinus Egyetem oktatója. A müben olyan szerződések bemutatásával foglalkozik, amelyek teljesítésére már a szerződéskötés időpontjában fennálló oknál fogva nem kerülhet sor. Vizsgálatának központi kérdése, hogy hogyan reagál a jogi szabályozás az ilyen típusú szerződésekre, mi a következménye, ha valaki lehetetlent ígér. A téma minél pontosabb és részletesebb feltárásához a szerző összehasonlító és történeti vizsgálati módszerek alkalmazását választotta. Így a római jogtól kiindulva a német és az angol jogfejlődésen keresztül ismerhetjük meg a szabályozásokat, azok változásait. (K. N.)

\section{- Hibás teljesítés}

BARTAl Géza-Farkas Attila

(Sorozat: Bírói Gyakorlat Füzetek, ISSN 2063-725X; 14.)

Opten, Budapest, 2015

Kézikönyv. Terjedelem: 211. Bibliográfia nincs. ISBN 9786155122200

- A szerzők kúriai bírák. A kötet öt fejezetben dolgozza fel a hibás teljesítés témakörét. Ehhez a joggyakorlatot hívja segítségül: minden fejezet témáját jogeseteken keresztül mutatják be. Elsőként a szerződés hibás teljesítésének köréből ismerhetünk meg eseteket, majd a kellékszavatosság témakörét, azon belül az egyes kellékszavatossági jogokat tekintik át. A következő fejezetben a kellékszavatossági határidők, majd a kártérítés és a jótállás szabályaival ismerkedhet meg az olvasó a bírósági ügyeken keresztül. Az utolsó fejezet a közös szabályokat, az eljárási és egyéb kérdéseket mutatja be. (K. N.)

- A polgári perrendtartásról szóló 1952. évi III. törvény nagykommentárja BerecZky Sára-Mohácsi Máté-Molnár Judit-NyILAS Anna-Osztovits AndrásPomeISL András-PribULa László-SURÁnYI-FaRKAS Sára-VILLÁm Krisztián-VIRÁg Csaba Opten, Budapest, 2015 
Kommentár. Terjedelem: 1377. Bibliográfia nincs. ISBN 9786155122088

- A szerzők polgári eljárásjoggal foglalkozó egyetemi oktatók, illetve gyakorló jogászok. A kommentár szerkezete a polgári perrendtartásról szóló 1952. évi III. törvény felépítését követi, mely kiegészül az Opten Kiadó kommentárjaitól megszokott rövid áttekintés beillesztésével. Nagy hangsúlyt kapott az egyes szakaszok elméleti hátterének bemutatása, kiegészítve a vonatkozó bírósági és alkotmánybírósági határozatokkal, illetve kollégiumi véleményekkel. A kommentár további pozitívuma, hogy a kapcsolódó jogszabályokra is utalást tesz, az egyes rendelkezések alaposabb megismerése érdekében. (F. Á.)

- A cégnyilvántartásról, a bírósági cégeljárásról és a végelszámolásról szóló 2006. évi V. törvény kommentárja

Bodnár Zsuzsanna-Fézer Tamás-Metzinger Péter-Osztovits András

Opten, Budapest, 2015

Kommentár. Terjedelem: 439. Bibliográfia nincs. ISBN 9786155122057

- A szerzők oktatók-kutatók és gyakorló jogászok. Az Opten Kiadó által megkövetelt módon szerkesztett kommentár a cégnyilvántartásról, a bírósági cégeljárásról és a végelszámolásról szóló 2006. évi V. törvény szerkezetét követi. Kezelhetőségét, hasznosíthatóságát segíti, hogy az egyes szakaszok előtt egy rövid áttekintésben összefoglalja az olvasó számára az ismertetésre kerülő föbb pontokat. Az elsősorban gyakorlati területeken dolgozó jogászok, bírák és ügyvédek számára készített kommentár, tekintettel a joggyakorlatra, a jogszabályi rendelkezések érvényesülésére vonatkozó megállapításaira, jó kiindulópont a tudományos kutatások számára is. (F. Á.)

- Kötelmi jog II. a 2013. évi V. törvény alapján: az új Polgári törvénykönyv szövegének rövid magyarázata

Csehi Zoltán (szerk.)

Menedzser Praxis, Budapest, 2015

Oktatási segédanyag. Terjedelem: 396. Bibliográfia nincs. ISBN 9789638998699

- Az „ideiglenes jegyzetnek” szánt kiadvány szerkesztője egyetemi oktató. A kötet az egyes nevesített szerződésekröl szóló rendelkezésekhez füz rövid magyarázatokat. Az új Ptk. hatálybalépése kardinális változásokat hozott e téren, így a mű szükségképpen kitér az új rendelkezésekre. Az első részben az egyes szerződésekről olvashatunk, a tulajdonátruházó szerződésektől kezdve a franchise szerződésen át az élettársi kapcsolatig, az összes nevesített szerződés szabályanyagával megismerkedhet az olvasó. A második részben az értékpapírokra vonatkozó jogi rendelkezésekröl szerezhetünk átfogó ismereteket. (K. N.)

- Gyermeki jogok, szülöi felelősség és gyermekvédelem

Filó Erika-Katonáné Pehr Erika

(Sorozat: Új Magánjog, ISSN 2064-7514; 10.)

HVG-ORAC, Budapest, 2015

Kézikönyv. Terjedelem: 391. Bibliográfia: 15. ISBN 9789632582702 
- A szerzők elismert gyakorlati szakemberek, illetve a Pécsi Tudományegyetem oktatói. A kézikönyv gyermekjogi megközelítésböl (a szakterület interdiszciplináris, ágazati jellegére figyelemmel), komplex módon dolgozza fel a gyermekvédelmi törvényt, a Polgári Törvénykönyv Családjogi Könyvét és az ENSZ Gyermek Jogairól szóló Egyezményt. Emellett megjelennek az ENSZ és az Európa Tanács gyermekeket érintő, többoldalú nemzetközi egyezményei, ajánlásai és az Európai Unió elsődleges jogforrásai, különösen az Új Brüsszel II. rendelet előírásai. Noha a szülői felelősségből indul ki a kötet, az állam támogató szerepét, kötelezettségeit is részletezi. Külön fejezetben foglalkozik a szülői felügyelettel, az örökbefogadás és gyámság témaköreivel. Jellemzésre kerül a gyermekvédelmi rendszer, a gyermekvédelmi ellátások és intézkedések rendszere, a gyámügyi igazgatás szervezete, feladata és föbb eljárási szabályai. (K. J.)

- Biztositási szerződések az egészségügyben

HidvéGiné AdorJán Lívia-SÁRINé Simkó Ágnes

Medicina, Budapest, 2015

Kézikönyv. Terjedelem: 479. Bibliográfia: 479. ISBN 9789632263571

- A szerzők gyakorló jogászok (egyikük nyugalmazott bíró, másikuk az új Polgári Törvénykönyv elökészítésének korábbi miniszteri biztosa). A kötet a biztosítók, biztosítottak, károsultak számára kíván tájékoztatást nyújtani a felelösségbiztosítások magyarországi lehetőségeiről. A biztosítások rövid történeti áttekintése után bemutatja a régi és az új Polgári Törvénykönyv kártérítésekre és biztosításokra (főként a szakmai felelősségbiztosításokra, egészségbiztosításokra) vonatkozó rendelkezéseit, de az egészségügyi törvény és több más jogszabály kötelező szakmai felelösségbiztosításra vonatkozó szabályait is kifejti. Az Európai Unió biztosítással kapcsolatos irányelveinek ismertetését az európai bírósági gyakorlatának bemutatása követi. Kitér a szakmai felelősségbiztosítások európai áttekintésére és összehasonlítására. Öt biztosítótársaság egészségügyi szolgáltatók részére kínált felelősségbiztosításait és szabályzatszövegét is feldolgozza. Ismertetésre kerül a biztosításokra vonatkozó magyar ítélkezési gyakorlat is. (K. J.)

- Kötelmi jog I. - A kötelmek közös szabályai, a szerződések általános szabályai, felelösségtan

JoBbáGYI Gábor

Szent István Társulat, Budapest, 2015

Tankönyv. Terjedelem: 214. Bibliográfia: 213-214. ISBN 9789632775043

- A szerző a Pázmány Péter Katolikus Egyetem oktatója. A tankönyv az új Ptk. alapján és rendszerében tárgyalja a kötelmi jog, a szerződések általános szabályait és a szerződésen kívüli felelősség szabályait. A törvény szövegének ismertetését követően megmagyarázza annak tartalmát, azonban ezen túlmenve kifejti az adott területen fontos és szükséges egyéb ismereteket, köztük a bírói gyakorlat tendenciáit is. A müvet rövid, lényegre törö fogalmazásmód jellemzi, a könnyebb befogadást és jobb megértést a joghallgatók korábbi tanulmányaira utaló, római jogi és jogtörténeti kapcsolódások segítik. (K. J.) 
- Nemzetközi magánjog és nemzetközi gazdasági kapcsolatok joga MÁDL Ferenc-VÉKÁs Lajos

(Sorozat: ELTE Jogi Kari Tankönyvek, ISSN 2060-6494; 8.)

Nyolcadik, átdolgozott kiadás. ELTE Eötvös Kiadó, Budapest, 2015

Tankönyv. Terjedelem: 557. Bibliográfia: 557. ISBN 9789633121313

- A szerzők az ELTE ÁJK nagynevü professzorai, illetve Mádl Ferenc (1931-2011) volt köztársasági elnök. A könyv első kiadása 1981-ben jelent meg; az újabb kiadásokat (különösen 2004-töl) a normaváltozások hívták életre, melyek közül a legfontosabbak a Brüsszel la. rendelethez köthetők. A könyv a nemzetközi magánjog általános kérdésein belül a nemzetközi magánjog fogalmával, a nemzetközi magánjog tudományának rövid történetével, a nemzetközi magánjog forrásaival ismerkedhetünk meg. A második cím foglalkozik a kollíziós szabályokkal, azok alkalmazásával, a minősítéssel, a vissza- és továbbutalással, a külföldi jog alkalmazásával és annak mellőzésével. Az ezt követő címek a személyek, a tulajdon, a szerződések jogát, a nemzetközi szerzői jog és iparjogvédelem alapjait, a nemzetközi öröklési jogot, a nemzetközi családjogot és a nemzetközi munkajogot ismertetik. Az utolsó cím a joghatóságról, eljárásról, külföldi határozatok elismeréséröl és végrehajtásáról szól. (K. J.)

- A fizetési meghagyásos eljárásról szóló 2009. évi L. törvény kommentárja MoLnÁR Judit-NYILAS Anna

Opten, Budapest, 2015

Kommentár. Terjedelem: 187. Bibliográfia nincs. ISBN 9786155122064

- A szerzők a Debreceni Egyetem Állam- és Jogtudományi Kar Polgári Eljárásjogi Tanszékének oktatói. A kommentár felépítése a fizetési meghagyásos eljárásról szóló 2009. évi L. törvény szerkezetét követi, törekedve a jogszabály ismertetésen túl a fizetési meghagyásos eljárás elméleti hátterének bemutatására is. A kommentár, amely elsősorban a jogalkalmazók számára készült, számos jogszabályra, különösen a Pp., Vht. és a Ptk. szabályaira történő utalással segíti a szabályozás áttekintését, valamint a vonatkozó bírói gyakorlatot is bemutatja. Pozitívuma az Opten Kiadótól már megszokott, az egyes szakaszok ismertetését megelőzően adott rövid áttekintés arról, hogy az adott fejezetben milyen kérdéskörökkel foglalkozik a kommentár. (F. Á.)

- Fizetésképtelenségi eljárások

Osztovits András

(Sorozat: Bírói Gyakorlat Füzetek, ISSN 2063-725X; 18.)

Opten, Budapest, 2015

Kézikönyv. Terjedelem: 202. Bibliográfia nincs. ISBN 9786155112248

- A szerző a Károli Gáspár Református Egyetem oktatója, kúriai bíró. A kézikönyv a fizetésképtelenségi eljárásokat, így a csődeljárást és a felszámolási eljárást, illetve az ahhoz kapcsolódó, elsősorban a bírói gyakorlatban felmerülö kérdésköröket veszi górcső alá. A kötet a Bírói Gyakorlat Füzetektöl megszokott módon bírósági eseti döntések tényállásainak részletes ismertetésével és a bírósági döntés értékelésével válaszolja meg az egyes fejezeteken belül feltett kérdéseket. 
Szerkezetileg hét fejezetet tartalmaz, ezek a csődeljárással, a felszámolási eljárás megindításával, a gazdálkodó szervezet vezetőjének kötelezettségeivel és felelősségével, a felszámolás elrendelésének következményeivel, a szerződések megtámadásával, a felszámoló eljárásával, valamint a felszámolási eljárás befejezésével foglalkoznak. (F. Á.)

- Ingatlan-nyilvántartás - Az új Ptk. alapján

PETRIK Ferenc

(Sorozat: Új Magánjog, ISSN 2064-7514)

HVG-ORAC, Budapest, 2015

Kézikönyv. Terjedelem: 542. Bibliográfia nincs. ISBN 9789632582719

- A szerző nyugalmazott bíró, aki az új polgári törvénykönyv hatálybalépését követően összefoglalta az ingatlan-nyilvántartás szabályanyagát. A kézikönyv a bevezetésben kitér az ingatlan-nyilvántartás elvi és történeti alapjaira, majd számba veszi az ingatlan-nyilvántartás mibenlétét, alapelveit, tárgyát és tartalmát, valamint az ingatlan-nyilvántartás egyes részeit és módját. A szerző a kézikönyv második felében az ingatlan-nyilvántartási eljárással kapcsolatos területeket elemzi, különösen magát az eljárást, a jogorvoslati rendszert, illetőleg a különleges eljárásokat. Az utolsó fejezetben a földmérési és térképkészítési tevékenységet mutatja be. A kézikönyv az egyes fejezeteken belül a jogszabály ismertetése mellett utal a régi Ptk. szabályozására, valamint számos alkotmánybírósági, illetve bírósági határozatra is kitér. (F. Á.)

- Polgári jog I-III. - Jogi szakvizsga könyvek

Sándor István (szerk.)

Patrocinium, Budapest, 2015

Oktatási segédanyag. Terjedelem: 371 (I. kötet), 429 (II. kötet), 483 (III. kötet). Bibliográfia nincs. ISBN 9789634130550 (I. kötet), 9789634130567 (II. kötet), 9789634130574 (III. kötet)

- A szerzők a KRE ÁJK oktatói, gyakorló ügyvédek. A háromkötetes mü tartalmilag és szerkezetileg is az Igazságügyi Minisztérium által kiadott, hivatalos jogi szakvizsgatételsorhoz igazodik, a joganyagot és a kapcsolódó bírósági gyakorlatot tételenként mutatja be. Az egyes kötetek az alábbi témaköröket fogják át: a polgári jog alapelvei, az ember mint jogalany, a személyiségi jogok és a dologi jog; kötelmi jog, a Ptk.-ban foglalt egyes szerződések; öröklési jog, családi jog. Minden kötet áttekinti a fontosabb fogalmakat, elveket, illetve bemutatja az egyes jogintézményeket. (K. N.)

- Decem anni in Europaea Unione III. - Civilisztikai tanulmányok

Sápi Edit (szerk.)

(Sorozat: Miskolci Jogtudományi Mühely, ISSN 1589-1518; 8.)

Miskolci Egyetemi Kiadó, Miskolc, 2015

Tanulmánykötet. Terjedelem: 286. Bibliográfia a lábjegyzetekben.

ISBN 9786155216794 
- A szerkesztő a Miskolci Egyetem ÁJK oktatója. Jelen kötet a 2014-es „Európai hatások a magyar magánjogi felelösség területein, különös tekintettel a kártérítési felelősségre” és a 2013-as „Korszakváltás a családjogban” című konferencia előadásainak az írásos anyagát tartalmazza. Az előbbi témát képviselő, tizenöt tanulmányban miskolci, valamint külföldi és belföldi társkari szerzők álláspontja kapott helyet, a kártérítés számos területéhez kapcsolódóan. A második rész öt tanulmányt tartalmaz magyar társkari kollégáktól, illetve gyakorló jogászoktól, melyek a házassági vagyonjoggal, a mediációval, a gyermekek jogellenes külföldre vitelével, illetve az örökbefogadás témakörével foglalkoznak. (K. N.)

- Gazdasági civiljog, kormányzástan, sportpolitika

SÁRKÖZY Tamás

HVG-ORAC, Budapest, 2015

Tanulmánykötet. Terjedelem: 423. Bibliográfia: 423. ISBN 9789632582764

- A szerző jogászprofesszor, számos gazdasági jogi munka szerzője. Ebben a müben három területre fókuszál. A kötet első részéhez kifejezetten jogi tanulmányok tartoznak, melyek jogelméleti és gazdasági civiljogi szemléletüek. A második tárgyalt téma a kormányzástan, amelyben a szerző a kormánypárti, illetve a rendszerváltozás utáni stratégiákat vizsgálja. Ennek keretein belül többek között értékeli a magyar kormányzást, bemutatja a „vezérdemokrácia” kormányzásának jellemzöit, valamint kitér az Alaptörvényre is. Az utolsó érdemi témakör a sportpolitika, amelynek keretei között a magyar sportokon belül a labdarúgásnak külön fejezetet szánt a szerző. A bevezetésben a szerzővel készült két interjú, míg a befejező részben a szerző által készített két interjú, és két - a szerző könyveiről készült - recenzió olvasható. (K. N.)

- Az egyesületek joga: egyetemi kari jegyzet

Sipos László

Debreceni Egyetemi Kiadó, Debrecen, 2015

Egyetemi jegyzet. Terjedelem: 253. Bibliográfia: 237-240. ISBN 9789633185346

- A szerző a Debreceni Egyetem Egészségügyi Karának docense. A mü lehetöséget ad arra, hogy az új civil törvény és az új Ptk. rendelkezéseit számba véve mutassa be az egyesületeket mint jogi személyiséggel bíró sajátos civilszervezeteket. Ennek érdekében az egyesületek általános és teljes körü szabályozását mutatja be, a létrehozástól egészen a megszűnésig, majd egyes speciális egyesületi formák szabályozására is kitér. A mű végén néhány, az egyesületeket segítő intézményt is bemutat, így kitér a Nemzeti Együttmüködési Alapra, a civil információs centrumokra, illetve a Civil Információs Portálra is. (K. N.)

- Családi jog

SzEIBERT Orsolya

Második, átdolgozott kiadás. ELTE Eötvös Kiadó, Budapest, 2015

Egyetemi jegyzet. Terjedelem: 323. Bibliográfia: 317. ISBN 9789633122242

- A szerző az ELTE ÁJK oktatója. A könyv címében megjelenő témakör a családi jog, a mü azonban kitér olyan elemekre is, amelyek a tárgykör szélesebb értelmü 
megközelítése kapcsán jelentősek, így az élettársi jogviszonyra, az élettársi kapcsolatból származó vagyonjogi perekre is. Foglalkozik ezenkívül a gyermekjogi, gyermekvédelmi vonatkozású kérdésekkel is, illetve bemutatja a különböző jogszabályok és az Alaptörvény családjogi vonatkozású rendelkezéseit is. A mü külön figyelmet fordít a korábban hatályos Csjt. törvény rendelkezéseire, melyek egy része továbbra is alkalmazandó, ugyanakkor külön kiemeli a fontosabb módosításokat. A Családi jog címmel, 2012-ben megjelentetett első kiadás új és átdolgozott változatáról van szó, amely a 2013. évi V. törvény, a Polgári Törvénykönyv családjogi rendelkezéseire tekintettel készült el. (K. N.) 